Received Date : 18-Feb-2016

Revised Date : 23-May-2016

Accepted Date : 23-May-2016

Article type : Original Article

\title{
Diversity of Phytophthora species in natural ecosystems of Taiwan and association with disease symptoms
}

T. Junga, ${ }^{*}$, T.T. Changc, J. Bakonyid, D. Seress', A. Pérez-Sierrae, X. Yangf, C. Hongf, B. Scanug, C.H. Fuc, K.L. Hsuehc, C. Maiaa, P. Abad-Camposh, M. Léonh, M. Horta Junga

aLaboratory of Molecular Biotechnology and Phytopathology, Center for Mediterranean Bioresources and Food (MeditBio), University of Algarve, Campus de Gambelas, 8005-130 Faro, Portugal; 'Phytophthora Research and Consultancy, Am Rain 9, 83131 Nußdorf, Germany; cForest Protection Division, Taiwan Forestry Research Institute, Taipei, Taiwan; dPlant Protection Institute, Centre for Agricultural Research, Hungarian Academy of Sciences, Herman Ottó út 15,

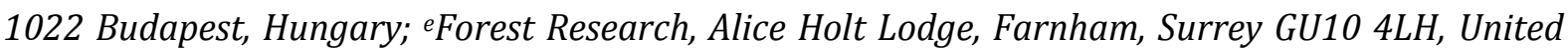
Kingdom; fHampton Roads Agricultural Research and Extension Center, Virginia Polytechnic Institute and State University, Virginia Beach, VA, USA; gDipartimento di Agraria, Sezione di Patologia vegetale ed Entomologia (SPaVE), Università degli Studi di Sassari, Viale Italia 39, 07100 Sassari, Italy; Instituto Agroforestal Mediterráneo, Universidad Politécnica de Valencia, Camino de Vera s/n, 46022 Valencia, Spain.

*Email: trjung@ualg.pt and dr.t.jung@t-online.de

This article has been accepted for publication and undergone full peer review but has not been through the copyediting, typesetting, pagination and proofreading process, which may lead to differences between this version and the Version of Record. Please cite this article as doi: 10.1111/ppa.12564

This article is protected by copyright. All rights reserved. 
In 2013 a survey of Phytophthora diversity was performed in 25 natural and semi-natural forest stands and 25 rivers in temperate montane and subtropical lowland regions of Taiwan. Using baiting assays, ten described species and 17 previously unknown taxa of Phytophthora were isolated from $71.5 \%$ of the 144 rhizosphere soil samples from 33 of 40 tree species sampled in 24 forest stands ,and from 19 rivers: P. capensis, P. citrophthora, P. plurivora, P. tropicalis, P. citricola VII, $P$. sp. x botryosa-like, $P$. sp. x meadii-like and $P$. sp. occultans-like from Clade 2; $P$. palmivora from Clade 4; P. castaneae and P. heveae from Clade 5; P. chlamydospora and P. sp. forestsoil-like from Clade 6; P. cinnamomi (Pc), P. parvispora, P. attenuata nom. prov., P. flexuosa nom. prov., P. formosa nom. prov., P. intricata nom. prov., P. x incrassata nom. prov. and $P . \mathrm{x}$ heterohybrida nom. prov. from Clade 7; P. sp. palustris and five new hybrid species from Clade 9. The A1 mating type of $P c$ was widespread in both montane and lowland forests and rarely associated with disease, whereas the A2 mating type was limited to lowland forests and in some cases causing severe dieback. Most other Phytophthora species were not associated with obvious disease symptoms. It is concluded that (1) Taiwan is within the center of origin of most Phytophthora taxa found, (2) PcA2 is an introduced invasive pathogen, and (3) interspecific hybridisations play a major role in speciation and species radiations in diverse natural ecosystems.

Key words: biosecurity, breeding systems, hybridisation, forest survey, river survey, centre of origin

\section{Introduction}

Many devastating declines of trees and natural ecosystems are driven by non-native Phytophthora species which remain unnoticed in their native environment and after their introduction to other continents became invasive, threatening a non-adapted flora which due to a lack of co-evolution contained a high number of susceptible species. Well documented examples include P. cinnamomi (Erwin \& Ribeiro 1996; Hardham 2005), P. lateralis (Erwin \& Ribeiro 1996), P. plurivora (Jung \& Burgess 2009; Jung et al. 2013) and P. ramorum (Rizzo et al. 2002).

This article is protected by copyright. All rights reserved. 
Due to its diversity of geology, geomorphology, macroclimate and orographic climates, the complex palaeoclimatic history, the repeated immigration of plant species from northern latitudes, the temporary connection of a multitude of islands to the mainland during glacial periods in the pleistocene followed by separation during interglacials, Southeast Asia is a hotspot of plant diversity (Gower et al. 2012). There is an accumulating body of evidence that $P$. cinnamomi, P. lateralis, P. plurivora and other important Phytophthora pathogens with global distribution are native to Southeast Asia suggesting this region might be one center of origin of the genus Phytophthora: the widespread occurrence of devastating Phytophthora diseases of horticultural trees and crops like Hevea brasiliensis (Phytophthora botryosa, P. capsici, P. citrophthora, P. heveae, P. meadii, P. palmivora), Theobroma cacao (P. cactorum, P. heveae, P. meadii, P. palmivora), Citrus spp. (P. citrophthora), Colocasia esculenta (P. colocasiae), Durio zibethinus (P. nicotianae, P. palmivora), Cinnamomum burmannii and Cinnamomum osmophloeum (P. cinnamomi), Piper nigrum (P. capsici, P. cinnamomi, P. nicotianae) and various horticultural herbs (P. citrophthora, P. nicotianae, P. palmivora, P. tropicalis) (Chang et al. 1996; Erwin \& Ribeiro 1996; Ho and Lu 1997; Drenth and Guest 2004; Zeng et al. 2009; Ann et al. 2010); occurrence of both mating types of several heterothallic Phytophthora species including P. botryosa, P. capsici, P. cinnamomi, P. colocasiae, P. meadii, P. nicotianae and P. palmivora (Ko et al. 1978, 2006; Arentz \& Simpson 1986; Ho 1990; Erwin \& Ribeiro 1996); and apparent absence of Phytophthora epidemics in natural ecosystems despite of presence of several Phytophthora species (Ko et al. 1978, 2006; Arentz \& Simpson 1986; Ho \& Lu 1997; Zeng et al. 2009; Brasier et al. 2010; Vettraino et al., 2011; Huai. et al., 2013). Phytophthora cinnamomi, arguably the world' s most notorious and widespread plant pathogen, was first described causing stripe cankers of cinnamon trees in Sumatra and it was suspected that the pathogen jumped from healthy surrounding rainforests onto the plantation trees (Rands 1922). In Northwestern Yunnan, $P$. chlamydospora, P. cryptogea, P. gonapodyides, P. gregata, P. lacustris, P. plurivora and two previously unknown Phytophthora species were isolated from soil samples of healthy undisturbed oak forests and from forest streams (Huai et al. 2013). In a remote subtropical to

This article is protected by copyright. All rights reserved. 
temperate forest area in Nepal, P. plurivora (previously named P. citricola), P. nicotianae and $P$. himalsilva were common in the rhizosphere of a range of broadleaved tree species without causing obvious disease symptoms (Vettraino et al. 2011). Phytophthora castaneae (previously named P. katsurae), P. cinnamomi, P. heveae, P. insolita, P. nicotianae and P. plurivora were widespread in soils and streams of protected, healthy montane forests in the tropical island of Hainan (Zeng et al. 2009). The best studied region of Southeast Asia regarding Phytophthora diversity is the island of Taiwan. Re-examining the original Phytophthora cultures collected by Sawada between 1911 and 1943 and reviewing more recent literature, Ho (1990) lists 21 valid Phytophthora species of which P. castaneae, P. cinnamomi and P. heveae were recovered from soils of natural forests without causing disease (Ko et al. 1978, 2006). More recently, Brasier et al. (2010) detected P. bisheria, P. cinnamomi and P. lateralis in healthy, undisturbed montane forest of Chamaecyparis obtusa.

Taiwan is located $130 \mathrm{~km}$ from mainland China between the Taiwan Strait and the Pacific around the tropic of Cancer and, despite its small size of $35.800 \mathrm{~km}^{2}$, harbours more than 4000 indigenous plant species of which more than 1000 are endemic (Chang-Fu et al. 1994). This high diversity and degree of endemism is related to Taiwan' s complex geology and geomorphology, the latter causing highly diverse precipitation patterns during winterly Northeast monsoons, and repeated temporary connections of the island to the Eastern Asiatic and Malesian Floristic Regions during glacial periods alternating with periods of isolation during the interglacials (Chang-Fu \& Chung-Fu 1994; Chang-Fu et al. 1994; Chung-Fu 1994). The Taiwanese flora contains 90 and 40 native species in 14 and 7 genera of the Lauraceae and Fagaceae, respectively, (http://www.efloras.org) both families known for the high susceptibility of many of their European and North American members to Phytophthora species (Rizzo et al. 2002; Jung 2009; Jung \& Burgess 2009; Hansen et al. 2012; Jung et al. 2013). Consequently, a high diversity of unknown Phytophthora species, posing a potential threat to European forests and natural ecosystems as a result of their co-evolution with tree species from genera also present in Europe, might be expected.

This article is protected by copyright. All rights reserved. 
In March and August 2013, in the frame of a collaborative research project between the University of Algarve and the Taiwanese Forestry Research Centre, a survey of Phytophthora diversity was performed in a diverse range of natural forest types and river systems across Taiwan. This paper reports on the results of this Phytophthora survey and the association of Phytophthora spp. with disease symptoms of forest trees in Taiwan, and discusses the potential threat posed by previously unknown Phytophthora spp. to European and North American forests.

\section{Material and methods}

\section{Sampling and Phytophthora isolation}

Twenty-five forest sites covering a wide range of tree species, climates and landscapes across Taiwan were selected for sampling (Figs. 1 and 2a-f). In addition, 25 rivers and streams were randomly selected during three trips around Taiwan for sampling soils from the forest sites (Fig. 1). Soil sampling and isolation methodology was according to Jung (2009). In total, 144 rhizosphere soil samples were taken from mature trees of 38 species in 24 natural forest stands and from young trees of 6 Quercus spp. and Rhododendron spp. in an arboretum (site F02) established ca 20 years prior in a natural subtropical Castanopsis - Machilus forest (F01; Table 1). Three soil monoliths with a size of $20 \times 30 \mathrm{~cm}$ were taken around each tree, at a distance of $30-150 \mathrm{~cm}$ from the stem base and at a soil depth of $10-30 \mathrm{~cm}$. Aliquots of rhizosphere soil together with roots (diameter $\leq 5 \mathrm{~mm}$ ) from all monoliths were bulked, and subsamples of ca. $200 \mathrm{ml}$ were used for isolation tests. Isolations from soil samples were carried out at $18-20^{\circ} \mathrm{C}$ in a walk-in growth chamber with 12 hrs natural daylight using 3- to 10-day-old leaflets of native species, mainly Quercus variabilis and Castanopsis indica, as baits floated over flooded soil.

Brownish leaflets were examined at x80 under a light microscope for presence of Phytophthora sporangia. Infected leaflets were blotted dry, cut into small segments and plated onto selective PARPNH agar (V8-juice agar (V8A) amended with $10 \mu \mathrm{g} / \mathrm{ml}$ pimaricin, $200 \mu \mathrm{g} / \mathrm{ml}$ ampicillin, 10 $\mu \mathrm{g} / \mathrm{ml}$ rifampicin, $25 \mu \mathrm{g} / \mathrm{ml}$ pentachloronitrobenzene (PCNB), $50 \mu \mathrm{g} / \mathrm{ml}$ nystatin and $50 \mu \mathrm{g} / \mathrm{ml}$

This article is protected by copyright. All rights reserved. 
hymexazol). Petri dishes were incubated at $20^{\circ} \mathrm{C}$ in the dark and examined for Phytophthora-like hyphae after 24-48 hours. In cases where no Phytophthora grew from leaves with typical Phytophthora sporangia on PARPNH, additional leaves were plated onto non-selective potatodextrose agar (PDA; Oxoid Ltd., UK).

Phytophthora isolations from the 25 rivers and streams were performed using a modified in situ baiting technique (Reeser et al. 2011; Hüberli et al. 2013). The baiting sites were mainly located inside or downstream of natural forests (Fig. 2g-h). Fly mesh and styrofoam were used to prepare $25 \times 30 \mathrm{~cm}$ bait bags rigged to float on the water surface (in the following called rafts; Fig. 2h). At each site, 10-15 non-wounded young leaves of Q. variabilis and other native Quercus spp., C. indica, Rhododendron spp., Citrus sinensis and in some cases Chamaecyparis obtusa, Cinnamomum camphora, Cinnamomum iners, Coffea arabica, Podocarpus nakaii and Zelkova serrata, were placed as baits in a raft, and the raft put to float at a place where water flow was calm. The rafts were collected after 2-3 days. Baiting leaves were washed in distilled water and blotted dry on filter paper. Five to ten pieces (approximately $2 x 2 \mathrm{~mm}$ ) were cut from the margins of each watersoaked or necrotic lesion of each leaf, blotted again on filter paper and plated onto PARPNH agar.

Pure cultures were obtained by transferring single hyphal tips from the edge of the colonies onto V8A. Stock cultures were maintained on carrot agar (CA; Scanu et al. 2014) at $10^{\circ} \mathrm{C}$ in the dark.

\section{Molecular identification of isolates}

For all Phytophthora isolates obtained in this study mycelial DNA was extracted from pure cultures grown in V8-juice medium. Total DNA was extracted using the DNeasy Plant Mini kit (QIAGEN, Hilden, Germany) following the manufacturer's instructions and checked for quality (gel electrophoresis on $0.7 \%$ agarose gels stained with ethidium bromide) and quantity (spectrophotometry, absorbance at $260 \mathrm{~nm}$ ). DNA was stored at $-20^{\circ} \mathrm{C}$ until further use.

This article is protected by copyright. All rights reserved. 
For all isolates the region spanning the internal transcribed spacer (ITS1-5.8S-ITS2) region of the ribosomal DNA was amplified using the forward primers ITS1 (White et al. 1990) or ITS6 (Cooke et al. 2000) and the reverse primer ITS4 (White et al. 1990). For representative isolates of several known and all putative new species the mitochondrial cox1 gene was amplified with primer-pairs COXF4N/COXR4N and FM84/FM83 as described by Kroon et al. (2004) and Martin \& Tooley (2003), respectively. The PCR reaction mixture and the amplification conditions for ITS and cox1 were as described by Cooke et al. (2000), Nagy et al. (2003), Martin \& Tooley (2003) and Kroon et al. (2004), respectively. PCR consumables were provided by Thermo Fisher Scientific Inc. (Waltham, MA USA). Thermocycles were carried out using Bio-Rad C1000 ${ }^{\mathrm{TM}}$ or Applied Biosystems ${ }^{\circledR} 2720$ Thermal Cyclers. PCR products were purified and sequenced by Macrogen Europe (Amsterdam, the Netherlands) in both directions with the primers used for PCR amplification.

Sequences were edited using the Sequencher software (Version 4.7, Gene Codes Corporation). Heterozygous sites observed were labelled according to the IUPAC coding system. Consensus sequences were aligned using the CLUSTAL W program. The consensus sequences were subjected to an NCBI BLAST search (http://www.ncbi.nlm.nih.gov/BLAST/) and to a blast search in a local database containing sequences of ex-type isolates or key isolates from published studies to identify the closest related sequences. Isolates were assigned to a species when sequence identities were above a 99\% cut-off in respect to those of ex-type isolates or key isolates. ITS sequences from representative isolates of all Phytophthora species and cox1 sequences of representative isolates of several known species and all putative new species obtained in this study were deposited at GenBank and accession numbers are given in Supplementary Table 1S.

This article is protected by copyright. All rights reserved. 


\section{Classical identification of isolates}

Colony growth patterns of 7-d-old cultures grown at $20^{\circ} \mathrm{C}$ in the dark on V8 agar (V8A), maltextract agar (MEA; Oxoid Ltd., UK) and PDA (Jung et al. 2011) and morphological features of sporangia, oogonia, antheridia, chlamydospores, hyphal swellings and aggregations were compared with known isolates and with species descriptions in literature.

Induction of sporangia formation and microscopic examinations and measurements of morphological structures at x200 and x400 were according to Jung et al. (2011) using a compound microscope (Zeiss Imager.Z2), a digital camera (Zeiss Axiocam ICc3) and a biometric software (Zeiss AxioVision). Self-sterile isolates were paired on V8A and CA with known A1 and A2 mating type tester strains of P. cinnamomi and P. cambivora (isolates with non-papillate sporangia) or P. botryosa, P. colocasiae and P. meadii (isolates with papillate sporangia), and examined after $4-6$ weeks incubation at $20^{\circ} \mathrm{C}$ in order to determine whether they are heterothallic or sterile (Jung et al. 2011). Selected isolates from putative new species were also mated with tester strains using the polycarbonate membrane method to produce selfed sexual structures (Yang \& Hong 2013). All isolates are preserved in the culture collection maintained at the University of Algarve.

\section{Results}

In total 401 isolates of 10 described species and 17 previously unknown taxa of Phytophthora were obtained from forest stands (Table 1) and river systems (Table 2) in Taiwan. GenBank accession numbers of ITS sequences of representative isolates of all 27 Phytophthora taxa and different haplotypes of P. cinnamomi, and of $\operatorname{cox} 1$ sequences of representative isolates of several described species and all new Phytophthora taxa are given in Supplementary Table 1S. Polymorphisms in ITS sequences differentiating Taiwanese haplotypes and the ex-type of $P$. cinnamomi are presented in Supplementary Table 2S. Polymorphisms in ITS and cox1 sequences separating most of the new Phytophthora species from Clades 2, 7 and 9 from closely related

This article is protected by copyright. All rights reserved. 
known species are shown in Supplementary Tables 3S-8S. Detailed descriptions of morphological characteristics, morphometric data, temperature-growth data and multigene phylogenies for all new Phytophthora species will be presented in separate publications.

\section{Phytophthora diversity in natural and semi-natural forest stands of Taiwan}

In 24 forest stands (96\%) 17 Phytophthora taxa were isolated from 103 of the 144 rhizosphere soil samples (71.5\%) of 33 of the 40 tree species sampled (82.5\%): P. castaneae, $P$. chlamydospora, P. cinnamomi, P. citrophthora, P. heveae, P. palmivora, P. parvispora, P. plurivora and a closely related new species from the 'P. citricola complex', two new species related to $P$. botryosa and P. meadii, four new species from Clade 7a and two new species from Clade 9 (Table 1). The only forest site from which no Phytophthora isolates could be obtained was the montane, warm-temperate Quercus glauca - Q. variabilis forest on the dry rocky peak of Huagang Mountain (F13). Here, however, an unknown Phytophthora species was abundantly forming papillate and bi-papillate, persistent sporangia of variable shapes on many $Q$. variabilis baiting leaves but could not be cultured after plating them onto both selective PARPNH agar and PDA despite repeated attempts.

Phytophthora cinnamomi was isolated from 59 rhizosphere soil samples (41\%) of 23 tree species $(57.5 \%)$ in 15 of the 25 forest stands sampled (60\%) making it by far the most widespread and common species. The A1 mating type of P. cinnamomi was present in 14 montane and lowland forests with an altitudinal amplitude ranging from 365 to $2287 \mathrm{~m}$ above sea level (asl). In contrast, the A2 mating type was only found in seven lowland forests located between 365 and $733 \mathrm{~m}$ asl (Table 1; Fig. 1). Both mating types co-occurred in six lowland forests. Interestingly, in three stands A1, A2 and homothallic A2 isolates, the latter stimulating oogonia formation in A1 isolates and readily producing oogonia in single culture, were found whereas none of the 52 A2 isolates from the Castanopsis-Machilus forest in Lenhuachih were able to produce oogonia in single culture (Table 1). Over all stands, the A1:A2 mating type ratio of the 183 isolates was $53.6: 46.4$ whereas in the six lowland stands with co-occurrence of both

This article is protected by copyright. All rights reserved. 
mating types the A1:A2 ratio of the 134 isolates was 41.8 : 58.2. In the Castanopsis-Machilus forest in Lenhuachih the A1:A2 mating type ratio of the 68 isolates was $33.5: 76.5$. The alignment of the ITS sequences including a short part of the $18 \mathrm{~S}$ region of the 183 isolates from this study and the ex-type isolate (CBS 144.22; GenBank no. HQ643189) from Sumatra revealed eight polymorphic sites, six indels and one deletion. The Taiwanese isolates belonged to eight haplotypes that differed from each other and from the ex-type isolate by 1-7 basepairs (bp) (Tables 1S, 2S). Four of the eight haplotypes comprised isolates from both mating types. Each of the other four haplotypes was only represented by one isolate, two of which were A1 and two were A2 (Table 2S). Single isolate haplotypes 1 and 8 had two and one heterozygous positions, respectively (Table 2S). The dominant haplotype 4 which was present in 13 stands comprised $72 \mathrm{~A} 1,54 \mathrm{~A} 2$ and 5 homothallic A2 isolates. With the exception of the montane coniferous forest in Chilan, where A1 isolates from haplotypes 4 and 6 were found, the seven montane forest stands infested by P. cinnamomi exclusively contained A1 isolates from haplotype 4. In contrast, in the seven lowland forests with presence of both mating types between two and four different haplotypes per stand were found. With each four haplotypes the highest diversity was found in the Castanopsis-Machilus forest F02 in Fushan (Fig. 2d) and in the evergreen Quercus forest F24 on the Hengchun Peninsula.

Although having been less frequently isolated than P. cinnamomi, P. castaneae (previously P. katsurae) from Clade 5 showed a similar altitudinal amplitude (440 - $2182 \mathrm{~m}$ asl) and geographical distribution as the A1 mating type of P. cinnamomi (Fig. 1). Phytophthora castaneae was isolated from Castanopsis, Lithocarpus, Quercus and Machilus spp. in four subtropical lowland stands, including the arboretum F01 in Fushan, the Castanopsis-Machilus forests F02 (Fig. 2d) and F15 in Fushan and Lenhuachih, and the broadleaved evergreen forest F20 on the southernmost Hengchun peninsula (Fig. 2f). In addition, it was recovered from Fagus hayatae and Chamaecyparis formosensis in the cool-temperate montane forests F04 (Fig. 2b) and F08 (Table 1; Fig. 1). All isolates matched the ITS sequence of the ex-type of P. castaneae (ICMP 19434; GenBank no. KP295319) except for one isolate from Fushan with two polymorphisms

This article is protected by copyright. All rights reserved. 
and two indels of $3 \mathrm{bp}$ and $1 \mathrm{bp}$, respectively, and two isolates from Hengchun Peninsula with another polymorphism (Table 1S). Phytophthora heveae from Clade 5 showed a more limited altitudinal distribution than its relative P. castaneae and was only found in four subtropical broadleaved forests below $365 \mathrm{~m}$ asl (Table 1; Figs. 1, 2e). The ITS and cox1 sequences (Table 1S) matched the ex-type of P. heveae (CBS296.29; GenBank nos. HQ643238 and HQ643238). The morphology of all isolates of $P$. castaneae and $P$. heveae was congruent with the original descriptions (Erwin \& Ribeiro 1996).

Phytophthora plurivora from Clade 2c was isolated from Alnus formosensis and Liquidambar formosensis at $1848 \mathrm{~m}$ asl in the montane, temperate and seasonally dry deciduous forest F12 in a remote area of the Central Mountain Ridge near Tunyuan (Table 1; Figs. 1, 2c). The morphology of the isolates and their ITS and cox1 sequences (Table 1S) conformed to the original description (ex-type CBS 124093; GenBank nos. FJ665225 and KC855435; Jung \& Burgess 2009). In a neighbouring montane forest (F11) at $2023 \mathrm{~m}$ altitude a new species from the 'P. citricola complex', designated as P. citricola VII, was isolated from the rhizosphere of $Q$. variabilis trees (Table 1; Fig. 1). It differed from its closest relatives P. citricola III (isolate 1E1; GenBank nos. of ITS and cox1 FJ392326 and GU071239), P. citricola sensu stricto (IMI021173; FJ237526 and FJ237512), P. pini (CBS181.25; FJ392322 and GQ247650) and P. plurivora (CBS 124093; FJ665225 and KC855435) in ITS by 2, 3, 5 and 5 bp, respectively, and in $\operatorname{cox} 1$ by 7, 13, 5 and $8 \mathrm{bp}$, respectively. Similar to all known species from the 'P. citricola complex', its morphology was characterised by a homothallic breeding system, paragynous antheridia and variable semipapillate sporangia.

A1 mating type isolates of P. parvispora which differed in ITS (Table 1S) from the ex-type of $P$. parvispora (CBS 132772; KC478667) by one heterozygous site were isolated from Glochidion rubrum in a subtropical lowland swamp forest on the Hengchun peninsula together with $P$. cinnamomi A1 (Tables 1, 1S; Fig. 1). Three other known Phytophthora species were also only sporadically isolated: P. chlamydospora from wet soil of ephemeral streambeds in two

This article is protected by copyright. All rights reserved. 
Chamaecyparis obtusa forests at Taiping Mountain and in Chilan above $1900 \mathrm{~m}$ altitude; $P$. citrophthora from Q. tarokoensis in Fushan arboretum and P. palmivora A1 from Zelkova serrata in a subtropical, evergreen lowland forest on the Hengchun Peninsula (Tables 1, 1S; Fig. 1).

Four new homothallic Phytophthora species from Clade 7a were detected in four natural forest stands and in the arboretum in Fushan (Tables 1, 1S; Fig. 1). They were clearly separated from each other and from their closest relatives by morphological characters, colony growth patterns, temperature-growth rates and multigene sequence differences which will be presented in detail elsewhere. Phytophthora attenuata nom. prov., which differed from its closest relatives $P$. fragariae and P. rubi in ITS by 6-7 bp and in cox 1 by $14 \mathrm{bp}$ and $10 \mathrm{bp}$, respectively, (Tables 3S, $4 \mathrm{~S}$ ) and in morphology by the production of ornamented oogonia with tapering bases, was recovered from C. formosensis and Castanopsis carlesii in two cool-temperate montane forests (F08, F10) growing above $2170 \mathrm{~m}$ altitude in Sheipa National Park (Figs. 1, 2a). Phytophthora flexuosa nom. prov., the closest relative of P. europaea (differences in ITS and cox1 of 1-2 bp and 9 bp, respectively; Tables 3S, 4S), was isolated alongside P. castaneae, P. cinnamomi A1 and Elongisporangium undulatum from Fagus hayatae in a cool-temperate montane forest on a remote mountain ridge in Taipingshan (F04; Figs. 1, 2b). Morphologically, it differed from $P$. europaea mainly by the production of ornamented, irregular-flexuose oogonia. Phytophthora formosa nom. prov., which is separated from P. attenuata nom. prov. in ITS and cox 1 by 6 bp and 8-9 bp, respectively, (Tables 3S, 4S) was associated with Araucaria cunninghamii in the subtropical Castanopsis-Machilus forest in Lenhuachih (F15) and with Quercus glandulifera in the arboretum in Fushan (F01) (Fig. 1). Phytophthora intricata nom. prov., the closest relative of P. formosa nom. prov. (differences in ITS and cox1 of $5 \mathrm{bp}$ and 6-7 bp, respectively; Tables 3S, 4 S) was exclusively found in the rhizosphere of Quercus tarokoensis trees in the arboretum in Fushan (F01). Morphologically, this species is characterised by twisted, intermingling oogonial and antheridial stalks and thickwalled oospores.

This article is protected by copyright. All rights reserved. 
Two new species from Clade 2a, informally designated as $P$. sp. $\mathrm{x}$ botryosa-like and $P$. sp. $\mathrm{x}$ meadii-like, were recovered from the rhizosphere of C. camphora, Styrax suberifolia, Glochidion philippicum and Trema australis trees growing in three subtropical, lowland monsoon forests (F17-F19) along the Pacific coast (Tables 1, 1S; Figs. 1, 2e). Phytophthora sp. x botryosa-like was separated from its closest relative $P$. botryosa by sequence differences of 7-13 and 16-19 bp in ITS and cox1, respectively, and from P. meadii by 11-15 and 5-12 bp in ITS and cox1 (Tables 5S, 6S). Phytophthora sp. x meadii-like differed in ITS and cox1 from its closest relative $P$. meadii by sequence differences of 5-13 and 5-12 bp, respectively, and from P. botryosa by 7-14 and 16-18 bp, respectively (Tables 5S, 6S). The occurrence of 10 heterozygous sites in their ITS sequences with 0-5 and 3-7 heterozygous sites per isolate, respectively, suggests a hybrid origin for both $P$. sp. x botryosa-like and P. sp. x meadii-like (Tables 5S, 6S). All isolates of both species belong to the A1 mating type, forming oogonia when mated with A2 tester strains of both P. botryosa and P. meadii, and produce papillate, bi-papillate or tri-papillate, variable and often caducous sporangia with short to medium-length pedicels suggesting an aerial lifestyle. In one of these lowland monsoon forests (F17) also a new species from Clade 9, P. sp. x Kunnunara-like, was isolated which is related to P. sp. Kunnunara (Tables 1, 1S, 7S, 8S; Fig. 1). A new sterile Phytophthora species was detected in the subtropical lowland swamp forest F20 on the Hengchun peninsula and is informally designated as $P$. sp. palustris (Tables 1, 1S; Fig. 1). This taxon was only distantly related to its nearest relatives in Clade 9, P. sp. x Hennops from river systems in South Africa (61 and $17 \mathrm{bp}$ sequence differences in ITS and cox1, respectively, to isolate CMW33363; GenBank nos. GU799663 and GU799640), P. virginiana (63 and 14 bp sequence differences in ITS and cox1, respectively, to the ex-type isolate 46A2; GenBank nos. KC295544 and KC295546) and $P$. sp. lagoariana (66 and 12 bp sequence differences in ITS and cox1, respectively, to isolate P8220, GenBank nos. HQ261695 and HQ261442).

This article is protected by copyright. All rights reserved. 
Besides many Pythium isolates which were not identified to species level, Phytopythium vexans was recovered from seven subtropical forests (F02 and F15-F19, F21), whereas

Elongisporangium undulatum and Elongisporangium anandrum were detected in two (F04, F06) and one (F08) montane temperate forest, respectively (Table 1).

Altitude had a strong influence on the composition of the Phytophthora populations in Taiwanese forest stands. Phytophthora attenuata nom. prov., P. flexuosa nom. prov., $P$. chlamydospora, P. plurivora and P. citricola VII only occurred in montane stands. In contrast, $P$. cinnamomi A2, P. citrophthora, P. heveae, P. intricata nom. prov., P. palmivora, P. parvispora, Phytophthora sp. x botryosa-like, P. sp. x meadii-like, P. sp. x Kunnunara-like, P. sp. palustris and P. formosa, the closest relative of the montane species P. attenuata nom. prov., were exclusively found in lowland forests. The only species with a wide altitudinal amplitude were P. cinnamomi A1 and $P$. castaneae.

\section{Phytophthora diversity in natural rivers of Taiwan}

Using rafts with leaves of $Q$. variabilis, $C$. sinensis, $C$. indica, Rhododendron spp. and in some cases C. camphora, C. iners, Z. serrata and other tree species as in situ baits, four known and 12 previously unknown Phytophthora species were isolated from 19 of the 25 rivers tested (76\%). Due to a typhoon with more than $500 \mathrm{ml}$ of precipitation within a few hours and the steep terrain, all tested rivers running from the Central Mountain Ridge to the Pacific coast including three of the six Phytophthora-negative rivers, Lee-wu River, Ma-tai-an River and La-ku-la-ku River, experienced severe floodings with extremely fast currents during the baiting period in August 2013. Four rivers that were originally included, Bei-gang River, North Qing-shui River, Wan-lee-qiao River and Fang-ping River, had to be discarded since the baiting rafts were found hanging dry in the canopy of riparian shrubs or buried underneath rocks.

This article is protected by copyright. All rights reserved. 
Most common were five new species from Clade 9 which were recovered from 12 watercourses located around the island (Table 1; Fig. 1). ITS and $\operatorname{cox} 1$ sequences of $P$. sp. x insolita-like (Table 1S) differed from its closest relative P. insolita (ex-type IMI288805; AF271222 and GU945482) by 6-12 bp and 4-9 bp, respectively. The ITS sequences of eight isolates from five rivers had in total 13 heterozygous sites with 2-8 heterozygous sites per isolate. There were no heterozygous sites in the $\operatorname{cox} 1$ sequences indicating that this taxon originated from sexual interspecific hybridisation. Similar to P. insolita, P. sp. x insolita-like produces oogonia without antheridia in single culture, non-papillate, internally proliferating sporangia, irregular hyphal swellings and thin-walled globose chlamydospores. The four new species $P$. sp. x virginiana-like 1 (5 rivers), $P$. sp. x virginiana-like 2 (7 rivers), P. sp. x virginiana-like 3 (5 rivers) and P. sp. x Kunnunara-like (9 rivers) were separated from their closest relatives $P$. virginiana, $P$. sp. lagoariana and $P$. sp. Kunnunara by ITS sequence differences of 1-12 bp (Tables 1S, 7S). The occurrence of in total 14, 24, 18 and 20 heterozygous sites, respectively, with 1-14 heterozygous sites per isolate, strongly suggests interspecific hybridisation (Table 7S). Cox1 sequences suggest as maternal parents $P$. sp. lagoariana for $P$. sp. x virginiana-like 1 and $P$. sp. $\mathrm{x}$ virginiana-like $3, P$. virginiana or $P$. sp. x Hennops for $P$. sp. x virginiana-like 2 and $P$. sp. Kunnunara for $P$. sp. x Kunnunara-like (Tables 1S, 8S). All four taxa are of silent A1 mating type (not forming oogonia but stimulating oogonia formation in A2 tester strains of $P$. cinnamomi in polycarbonate membrane mating tests) and produce globose, club-shaped and irregular swellings and globose thin-walled chlamydospores, typical features of aquatic Clade 9 species including P. virginiana (Yang \& Hong 2013).

Phytophthora capensis from the 'P. citricola complex' in Clade 2c was isolated from a tributary of Hapen River in Fushan and a tributary of Bei-shih river neir Pingling Township, both located in the northeast part of Taiwan (Table 2; Fig. 1). The ITS and cox1 sequences (Table 1S) and the morphology of all isolates were congruent with the original description (Bezuidenhout et al. 2010). From Cu-keng River in Fushan and from the tributaries of Hapeng River and Bei-shih River, a Phytophthora species from Clade 2a was recovered which in ITS shows $100 \%$ identity to

This article is protected by copyright. All rights reserved. 
P. occultans isolates from Europe and Oregon (Man In' t Veld et al. 2015; Reeser et al. 2015) and differences of 2 bp to P. himalsilva, 3 bp to P. terminalis, and 3-5 bp to P. citrophthora (Vettraino et al. 2011; Tables 2, 1S, 5S). However, in $\operatorname{cox} 1$ the isolates from Taiwan were much closer to $P$. himalsilva from Nepal ( $7 \mathrm{bp}$ difference to the ex-type isolate) than to P. occultans (28 bp difference) and $P$. citrophthora (28-30 bp) (Tables $1 \mathrm{~S}, 6 \mathrm{~S})$. This new taxon which is informally designated as $P$. sp. occultans-like shares with both P. occultans and P. himalsilva the homothallic breeding system and the production of papillate, highly variable caducous sporangia. The other two new species from Clade 2a, $P$. sp. x botryosa-like and $P$. sp. x meadiilike, were both recovered from Xiao-Qingshui Creek which is flowing from Taroko National Park through a subtropical evergreen monsoon forest (F16) to the Pacific coast (Tables 2, 1S; Fig. 1). The Clade 2b species P. tropicalis was detected in two tributaries of Da-jia River (Table 2; Fig. 1) which are surrounded by both evergreen broadleaved forests and plantations of betel nut (Areca catechu). Phytophthora parvispora from Clade 7 was also isolated from one of these streams and from the Ma-zhu-kung and Shui-she-shui-wei Rivers (Table 2), all located in the Western foothills of Taiwan (Fig. 1). All isolates of P. tropicalis and P. parvispora belonged to the A1 mating type and their morphology and ITS sequences (Table 1S) matched the original descriptions (Aragaki \& Uchida 2001; Scanu et al. 2014).

Phytophthora formosa nom. prov. and two other new species from Clade 7a were isolated from the tributary of Hapen River upstream of the arboretum in Fushan, and from Hapen River and Cu-keng River flowing through the subtropical Castanopsis-Machilus forests in Fushan (Table 2; Fig. 1): Phytophthora x heterohybrida nom. prov. and P. x incrassata nom. prov. share main morphological characters with their closest relative P. cambivora such as fluffy colonies on all agar media used, a heterothallic breeding system, production of large non-papillate sporangia and ornamented oogonia with amphigynous antheridia and absence of chlamydospores. The ITS sequences of $P . \mathrm{x}$ heterohybrida nom. prov. and $P$. x incrassata nom. prov. show 11-19 bp and 714 bp differences to P. cambivora and have four and five heterozygous sites, respectively, indicating interspecific hybridization (Tables $1 \mathrm{~S}, 3 \mathrm{~S}$ ). The $\operatorname{cox} 1$ sequences of $P$. x heterohybrida

This article is protected by copyright. All rights reserved. 
nom. prov. and P. x incrassata nom. prov. differed from P. cambivora by $7 \mathrm{bp}$ and $13 \mathrm{bp}$, respectively (Tables $1 \mathrm{~S}, 4 \mathrm{~S}$ ). All isolates of $P$. x incrassata nom. prov. belonged to the A2 mating type while for $P$. x heterohybrida nom. prov. isolates from both mating types plus A1/A2 isolates, which formed oogonia in mating tests with both A1 and A2 strains, were obtained.

Phytophthora chlamydospora from Clade 6 was isolated from $\mathrm{Cu}$-keng River in Fushan while P. sp. forestsoil-like, a new Clade 6 species with 10-15 bp and 34-36 bp differences in ITS and cox1, respectively, (Table 1S) to its closest relatives P. taxon 'forestsoil' (P1054; AF541908 and JN935966) and P. taxon 'hungarica' (isolate H-8/02; EF522141 and JN935964) was recovered from Cu-keng River and the tributary of Hapen River in Fushan (Table 2; Fig. 1).

With six Phytophthora species and three different mating types (A1, A2, A1/A2) of P.x heterohybrida nom. prov. the tributary of Hapen River in Fushan showed the highest Phytophthora diversity followed by Da-an River in Taichung County and San-zhan River in Hualien County with each five Phytophthora species (Table 2). In March predominantly species from Clade 7a, and P. capensis, $P$. sp. occultans-like and $P$. sp. forestsoil-like were found whereas in August the five new taxa from a high-temperature tolerant cluster of Clade 9 and the high temperature species $P$. parvispora and $P$. tropicalis prevailed.

\section{Association between Phytophthora presence in the rhizosphere and disease symptoms}

In the majority of sampled forests (Fig. 2a-f) most of the 33 tree species from which Phytophthora species were recovered, including Alnus formosana, Araucaria cunninghamii, Castanopsis faberi, C. indica, Chamaecyparis formosensis, C. obtusa, Cinnamomum camphora, Fagus hayatae, Glochidion philippicum, G. rubrum, Liquidambar formosana, Lithocarpus hancei, L. shinsuiensis, Machilus kusanoi, M. thunbergii, Quercus aliena, Q. glauca, Q. variabilis, Styrax suberifolia and Zelkova serrata, appeared generally healthy. Symptoms indicative of Phytophthora diseases were only found in five of the 25 forest stands sampled.

This article is protected by copyright. All rights reserved. 
In the subtropical Castanopsis-Machilus forest in Lenhuachih (F15) dieback of the upper crowns was observed in individual trees of Castanopsis kawakami and $C$. uraiana with presence of $P$. cinnamomi A1 and A2 or P. castaneae in their rhizosphere (Fig. 3a). All trees of M. kusanoi and M. thunbergii appeared healthy. In the subtropical Castanopsis-Machilus forest F02 located in the hills around the arboretum in Fushan (F01) patches of trees of C. carlesii, C. micranthum and Diospyros morrisiana showed severe thinning and dieback of crowns (Fig. 3b-e) and mortality. In addition, several $C$. carlesii trees were suffering from bleeding cankers at the stembase (Fig. 3f). The visual examination of root samples from five declining C. carlesii trees and three declining trees each of $C$. micranthum and D. morrisiana, all infested by P. cinnamomi and/or P. castaneae, demonstrated in all three tree species severe losses of lateral roots and fine roots and dieback of small woody roots (Fig. 4a-d). No symptoms of decline were found in M. kusanoi, M. thunbergii and L. hancei. At a recently disturbed site (construction of a trekking path) in the upper montane evergreen broadleaved forest F09 in Sheipa National Park, trees of Q. morii and Q. sessilifolia growing in a loamy soil infested by P. cinnamomi A1 showed severe thinning and dieback of crowns (Fig. 3g), mortality and excessive losses of lateral roots and fine roots (Fig. 4e). In the subtropical evergreen broadleaved forest F24 on Hengchun Peninsula, severe crown dieback and high mortality was observed in Quercus championii trees with presence of $P$. cinnamomi A1 and A2 in their rhizosphere while Quercus longinux trees appeared healthy. Unfortunately, crown symptoms could not be documented since the sampling was performed during a typhoon. Crown dieback and mortality was also found in Trema orientalis trees in the subtropical evergreen monsoon forest F19 which was infested by P. sp. meadii-like.

\section{Discussion}

The survey performed in each of 25 natural or semi-natural forests and rivers in Taiwan revealed the presence of ten described species and 17 previously unknown taxa of Phytophthora. Considering Taiwan' s size of approximately $36,000 \mathrm{~km}^{2}$, the low number of sampling sites and the fact that each site was sampled only once, such a Phytophthora diversity

This article is protected by copyright. All rights reserved. 
is unrivalled. The three most common and most widespread Phytophthora species detected in Taiwanese forests in this and in previous studies (Ko et al. 1978, 2006), P. cinnamomi, P. heveae and $P$. castaneae, also occur in montane forest soils on the tropical island Hainan in the South China Sea (Zeng et al. 2009). The overall diversity of recovered Phytophthora species from forests and rivers in Taiwan was much higher than that in Hainan. This may be due to the focus of the Hainan survey on agricultural crops, from which in total 13 Phytophthora species had been isolated (Zeng et al. 2009), and the fact that the baiting methods used in the present study had been optimized for the detection of Phytophthora species from forest soils and river systems (Jung 2009; Jung et al. 2011). Including recent findings of P. lateralis and P. bisheria in Chamaycyparis obtusa forests in Taiwan (Brasier et al. 2010) ten described species and nine previously unknown taxa of Phytophthora have so far been detected in less than 30 Taiwanese forest stands. In comparison, in more than one thousand mixed forest and riparian stands of $F$. sylvatica, Quercus spp. and Alnus spp. sampled across Europe 24 Phytophthora species were isolated (summarized in Jung et al. 2013) of which only five are considered as indigenous (Jung et al. 2015). Of the 19 Phytophthora species present in Taiwanese forests, only $P$.

chlamydospora, P. cinnamomi, P. citrophthora, P. lateralis and P. plurivora, also occur in European forests and woodlands. In North American forests, Phytophthora diversity appears to be lower than in Taiwan and Europe. In 125 oak forests sampled across the Eastern and NorthCentral US, four described and three previously unknown Phytophthora species were found with P. cinnamomi A2 being most common (Balci et al. 2007). Large-scale surveys with more than 10000 soil, canopy drip and tissue samples from Quercus, Notholithocarpus, Castanopsis and mixed conifer forests in the Western US revealed the presence of 12 Phytophthora species most of them considered as introduced invasive pathogens (Hansen et al. 2012). The Phytophthora populations in forests of Taiwan and North America had only three species in common, P. chlamydospora, P. cinnamomi A2 and P. heveae.

This article is protected by copyright. All rights reserved. 
With four known Phytophthora species, P. capensis, P. chlamydospora, P. parvispora and $P$. tropicalis, and 14 previously unknown Phytophthora taxa in Clades 2, 6, 7 and 9 recovered from 19 of the 25 rivers and streams tested riparian Phytophthora diversity in Taiwan was also high. From a single baiting raft in the tributary of Hapen Stream running through the arboretum and subtropical forest in Fushan six Phytophthora species including three different mating types of the new hybrid species $P$. x heterohybrida nom. prov. were isolated. The few negative results were most likely caused by extremely fast waterflow during typhoon-related floodings which prevented attachment of zoospores to baiting leaves. In recent years, a series of river surveys have been conducted in several countries all of which demonstrated an impressive diversity of both known and previously unknown Phytophthora species. In Yunnan, six known and two new Phytophthora species were isolated from small forest streams with the globally distributed species P. chlamydospora being the only species common to Yunnan and Taiwan. In South Africa, five described species, one designated taxon and five new taxa of Phytophthora were recovered from eight river systems (Oh et al. 2013). Besides $P$. chlamydospora also P. capensis and $P$. parvispora occurred in rivers of both South Africa and Taiwan (Oh et al. 2013). Another similarity between both surveys was the dominance of previously unknown Clade 9 species in the majority of rivers. In another river survey in South Africa a range of Phytophthora hybrids from Clade 6 were found (Nagel et al. 2013). Besides multiple Clade 6 hybrid taxa eight known Phytophthora species and four previously unknown Phytophthora taxa were isolated from 48 river systems across Western Australia (Hüberli et al. 2013; Burgess 2015). The remarkable lack of common species between the riparian Phytophthora populations in Taiwan and Western Australia, with the exception of P. parvispora, most likely reflects the biogeographical separation between both regions and the vastly different floristic and climatic conditions. Similarly, only one Phytophthora species, P. chlamydospora, was common to the riparian Phytophthora populations in Taiwan and North America. In Tennessee with two baiting periods in spring and autumn, six described and six unknown species of Phytophthora were found in 16 rivers while a large-scale survey in 65 rivers in Oregon with 5 or 38 baiting periods over two years

This article is protected by copyright. All rights reserved. 
demonstrated the presence of 13 described and one new Phytophthora species (Reeser et al. 2011; Shrestha et al. 2013). In Alaska, where like in Taiwan baitings were performed at one occasion, only two known and two new Phytophthora species were baited from 49 rivers and streams (Reeser et al. 2011). In Europe, apart from a survey in the Spanish Pyrenees using a metagenomic approach which will be discussed below, no data from surveys of riparian Phytophthora populations have been published. However, in an ongoing country-wide Phytophthora survey of natural ecosystems in Portugal 21 Phytophthora species have so far been obtained from 35 rivers and streams (M. Horta Jung, L. Schena, S. Mosca, C. Maia, A. Cravador and T. Jung, unpublished results). Remarkably, the new Clade 6 species $P$. sp. forestsoil-like was the only Phytophthora species common to river systems in Taiwan and Portugal, possibly as a result of long-standing trade relation between both countries reaching back to the 16 th Century.

Only six of the 15 Phytophthora species recovered from forest stands, P. chlamydospora, $P$. formosa nom. prov., P. parvispora, P. sp. x botryosa-like, $P$. sp. x meadii-like and P. sp. x Kunnunara-like, were also detected in rivers. Interestingly, the two most common Phytophthora species in Taiwanese forests, P. cinnamomi and P. castaneae, were never isolated from rivers running through or originating from infested forests. Likewise, 10 of the 16 Phytophthora species obtained by stream baiting could not be isolated from forest soils. These results strongly indicate that the majority of Phytophthora species are adapted to a specific lifestyle, either as soil- (or airborne) pathogens or as waterborne saprotrophs and opportunistic pathogens, and underscore the necessity of doing both soil and stream baiting for getting an overview of Phytophthora diversity in a diverse landscape. Alternatively, novel metagenomic approaches using high-throughput pyrosequencing, Phytophthora-specific primers and environmental DNA from soil and water samples can be used to unravel the true Phytophthora diversity in natural ecosystems (Català et al. 2015). Applying such an approach in two forest areas in Northern Spain, the presence of 13 and 35 Phytophthora taxa was demonstrated in forest soils and streams, respectively (Català et al. 2015). Interestingly, all Phytophthora species from forest

This article is protected by copyright. All rights reserved. 
soils were also detected in water samples. However, besides the risks of producing false Molecular Operational Taxonomic Units (MOTUs) due to sequencing errors and false-positives due to cross-contamination the major limitation of metagenomic approaches is the lack of isolates which are needed for the taxonomic description and host range testing of new Phytophthora species. Consequently, in future surveys both classical baiting methods and novel metagenomic approaches should be applied in parallel.

The high Phytophthora diversity in Taiwan is most likely caused by the island' s remarkable complexity of geomorphology and orographic climates, the high diversity of ecosystems and plant species with a high degree of endemism, and the repeated temporary connections to mainland Asia during glacial periods followed by periods of separation during interglacials (Chang-Fu \& Chung-Fu 1994; Chang-Fu et al. 1994; Chung-Fu 1994) allowing immigration of Phytophthora species and subsequent speciations and species radiations. In this survey, 15 Phytophthora species from Clades 2a, 7a and 9, respectively, were detected in natural ecosystems in Taiwan often co-occurring in the same forest or river. However, none of their known closest relatives like P. botryosa and P. meadii, both widespread in Southeast Asia (Erwin \& Ribeiro 1996), and P. himalsilva, P. terminalis and P. occultans from Clade 2a (Vettraino et al. 2011; Man In' t Veld et al. 2015), P. rubi, P. europaea, P. uliginosa and the globally distributed forest pathogen P. cambivora from Clade 7a or P. virginiana, P. parsiana, P. hydropathica, P. sp. lagoariana, P. sp. Kunnunara and P. sp. x Hennops from Clade 9 (Yang \& Hong 2013; Martin et al. 2014) were isolated in this or previous studies (Ko et al. 1978, 2006; Brasier et al. 2010). This suggests sympatric species radiation following the introduction of either common ancestors with their closest relatives or of their closest relatives themselves which were later outcompeted by the emerging new species. Apparently, in this process interspecific hybridisations were playing an important evolutionary role since nine of the 16 new species, $P$. sp. $\mathrm{x}$ botryosa-like, $P$. sp. x meadii-like, $P . \mathrm{x}$ incrassata nom. prov., $P . \mathrm{x}$ heterohybrida nom. prov., P. sp. x insolita-like, P. sp. x kunnunara-like, P. sp. x virginiana-like 1, P. sp. x virginiana-like 2 and $P$. sp. $\mathrm{x}$ virginiana-like 3 , are putative hybrids as indicated by multiple heterozygous sites in 
their ITS sequences. Interestingly, 1-2 heterozygous sites were also present in the ITS sequences of several isolates of P. cinnamomi A2 (haplotypes 1 and 8) and P. parvispora. Due to its multicopy nature the ITS rDNA gene region is of limited use for hybrid studies (Nagel et al. 2013; Burgess 2015). Therefore, sequencing of additional mitochondrial genes and cloning of single-copy nuclear genes to confirm the hybrid status and elucidate the parental species of all putative Taiwanese hybrid taxa, and flow cytometry analysis to clarify their ploidy status are currently underway.

Since most forest stands were natural and the catchments of most rivers were also covered by natural forests it is likely that Taiwan is within the center of origin of most Phytophthora taxa found. This is supported by the lack of disease symptoms in most sampled forest stands indicating a host-pathogen equilibrium resulting from long-term co-evolution. For $P$. plurivora from the 'P. citricola complex' in Clade 2c, an invasive wide-host range pathogen involved in decline and dieback of F. sylvatica, Quercus spp. and other important forest tree species in Europe (Jung 2009; Jung \& Burgess 2009; Jung et al. 2013), a Southeast Asian origin had been suggested (Jung \& Burgess 2009) which is supported by the detection of P. plurivora in undisturbed, healthy remote mountain forests in Central Taiwan in this survey and by recent findings in healthy broadleaved forests in montainous regions of Nepal and Yunnan (Vettraino et al. 2011; Huai et al. 2013). The detection of the new species $P$. citricola VII from the 'P. citricola complex', and the findings of $P$. capensis, which constitute the first record of this species from the 'P. citricola complex' outside of South Africa, and of P. plurivora, P. citrophthora, P. tropicalis and the three new Clade 2 a species $P$. sp. x botryosa-like, $P$. sp. x meadii-like and $P$. sp. occultans-like from natural ecosystems in Taiwan together with the widespread occurrence of P. botryosa, P. citricola, P. colocasiae and P. meadii across Southeast Asia (Erwin \& Ribeiro 1996; Ho and Lu 1997; Drenth \& Guest 2004; Zeng et al. 2009; Ann et al. 2010) suggest this region as the centre of origin of Phytophthora major Clade 2. Interestingly, isolates of $P$. sp. occultans-like from three rivers in Northeastern Taiwan were a 100\% match in ITS to P. occultans isolates from Europe and Oregon (Man In't Veld et al. 2015; Reeser et al. 2015) while their cox1

This article is protected by copyright. All rights reserved. 
sequences were much closer to P. himalsilva from Nepal (Vettraino et al. 2011) and to $P$. terminalis than to P. occultans. This supports the hypothesis of Man In't Veld et al. (2015) that $P$. himalsilva, P. occultans and $P$. terminalis are young emerging species originating from a common ancestor after recent geographic separation. The detection of six new species from Clade 7a in natural forests and forest streams of Taiwan in this work almost duplicates the number of species in this important subclade suggesting Southeast Asia as centre of origin of Clade 7a. Also P. heveae and P. castaneae from Clade 5, P. parvispora (Clade 7) and P. insolita (Clade 9) are considered being native to Taiwan and Southeast Asia (Erwin \& Ribeiro 1996; Ko et al. 2006; Zeng et al. 2009; Scanu et al. 2014) which is supported by results of this study. However, with the heterothallic species P. cinnamomi the situation is more complex and requires a separate consideration of the two mating types. Phytophthora cinnamomi is the most notorious wide-host range plant pathogen globally, causing epidemic dieback and mortality of more than 3000 woody species in natural ecosystems, nurseries and planted stands (Erwin \& Ribeiro 1996; Hardham 2005). On a global scale, the A2 mating type is far more widespread than the A1 mating type and the success of P. cinnamomi is mainly based on the spread of two clonal A2 lineages (Dobrowolski et al. 2003). In contrast in Taiwan, using a RAPD analysis Chang et al. al. (1996) found high genetic variability among P. cinnamomi isolates of both mating types. This is confirmed by the finding of a diverse P. cinnamomi population with eight ITS haplotypes and both mating types in the present study. The A1 mating type is common in both lowland and montane forests and usually not causing disease symptoms whereas the A2 mating type is restricted to lowland forests where it is in several cases associated with severe decline and dieback of native tree species. Interestingly, most severe crown dieback and mortality of trees were found in the Castanopsis-Machilus forest in Fushan and in the evergreen Quercus championii forest on the Hengchun Peninsula where the P. cinnamomi populations showed the highest diversity with each four ITS haplotypes and co-occurrence of both mating types, suggesting an interbreeding population. Also in Papua New Guinea, the A2 mating type of $P$. cinnamomi was exclusively found in lowland stands causing disease symptoms of trees and

This article is protected by copyright. All rights reserved. 
crops whereas the A1 mating type was widespread in natural montane forests without association to decline or dieback of trees (Arentz \& Simpson 1986). The apparent differences in climatic amplitudes between both mating types indicate that they became geographically separated a long time ago, most likely during the pleistocene, and then adapted to the environmental conditions prevailing in their respective habitats. The results from this study suggest that in Taiwan the A1 mating type was introduced via a landbridge during the pleistocene and became naturalised while the A2 mating type is most likely a recently introduced invasive pathogen which is still spreading. The latter hypothesis is supported by the comparison of data obtained from the natural Castanopsis-Machilus forest in Lenhuachih (F15) during this study with those of Ko et al. (1978) from the same stand. In the 1970s this forest was healthy and the A1 : A2 mating type ratio was 84.6 : $15.4(\mathrm{n}=13)$ (Ko et al. 1978). Thirty years later Castanopsis trees showed crown dieback and the A1 : A2 mating type ratio had changed to 33.5 : $76.5(\mathrm{n}=68)$. A population-genomic study of a global collection of $P$. cinnamomi including isolates from Taiwan and other locations in Southeast Asia is currently underway to unravel the origin of both mating types of this important pathogen. Phytophthora species from Clades $1(P$. cactorum, P. infestans, P. nicotianae), 4 (P. palmivora), 8 (P. cryptogea, P. drechsleri, P. porri) and 10 (P. boehmeriae) are causing diseases of commercial horticultural crops and ornamental plants in Taiwan, Hainan and China (Ho and Lu 1997; Zeng et al. 2009; Ann et al. 2010). However, the complete absence of Phytophthora species from Clades 1, 3, 8, 10 and, with the exception of one isolate of P. palmivora, also Clade 4 in the present survey makes it unlikely that these five phylogenetic clades are native to Taiwan and Southeast Asia.

In a preliminary pathogenicity trial of this study using underbark inoculation pathogenicity of $P$. cinnamomi to D. morrisiana and Q. morii was demonstrated (data not shown). In the frame of a host range test of $P$. cinnamomi among native Taiwanese Quercus species which will be published separately, $P$. cinnamomi caused extensive root root and mortality of $Q$. morii saplings in a soil infestation test fulfilling Koch' s postulates for this pathosystem (T. Jung and M. Horta Jung, unpublished data).

This article is protected by copyright. All rights reserved. 
The absence of decline and dieback in the majority of Phytophthora-infested forests in Taiwan suggests long-term co-evolution between the pathogens and a flora which contains a wide variety of tree species from genera also present in Europe and North America, including Quercus, Fagus, Castanea, Abies, Pinus and Picea. Therefore, high aggressiveness of indigenous Taiwanese Phytophthora species to endemic non-coevolved European and North American tree species can be expected as has already been demonstrated by P. cinnamomi and P. plurivora. For example, in a soil infestation test, the six new species from Clade 7a proved to be pathogenic to root systems of $C$. sativa and $F$. sylvatica with the two hybrid species $P$. x incrassata nom. prov. and P. x heterohybrida nom. prov. being highly aggressive to C. sativa (T. Jung and M. Horta Jung, unpublished results). These results are of great concern because more than a billion plants-forplanting are imported annually from Asia to Europe (Ludovic Rigoux, Université Libre de Bruxelles, Belgium, personal communication). Recently, a Europe-wide study demonstrated the widspread presence of 68 Phytophthora species in European nurseries and plantings, of which at least 47 are considered of exotic origin (Jung et al. 2015). Against this background, the widespread occurrence of a high number of previously unknown Phytophthora species in forests and rivers in Taiwan and elsewhere in Asia (eg. Huai et al. 2013) and in horticultural production areas in Japan (eg. Rahman et al. 2014) potentially poses a serious threat to forestry, horticulture, conservation and biodiversity in Europe and North America.

As a pro-active approach to plant biosecurity, further Phytophthora surveys in natural ecosystems in other regions of Asia and also in Africa and South America coupled with extensive host range testing of new Phytophthora species amongst major European tree species and agricultural crops are needed. Data generated by these surveys and trials will enable decision makers like the EU standing committee of plant health, EPPO, NAPPO, APHIS, WTO and national plant protection organisations to adapt outdated plant health laws and regulations (Brasier 2008; Jung et al. 2015). In addition, such Phytophthora surveys will give a clearer picture of natural species distribution and global diversity of the important oomycete genus Phytophthora

This article is protected by copyright. All rights reserved. 
and help to develop a deeper understanding of the factors driving diversity and adaptation including the frequency and the role of interspecific hybridisations in natural ecosystems.

\section{Acknowledgements}

The authors are grateful to the Portuguese Science Foundation (FCT) for financing the Exploratory Project EXPL/AGR-FOR/1304/2012 'Screening of Asian oak species for potential resistance to Phytophthora spp.' (QuerResist) and to Phytophthora Research and Consultancy for co-funding the visits to Taiwan. The Taiwan Forestry Research Institute in Taipei is acknowledged for providing a car with driver, lab spaces, consumables and technicians. DNA sequencing in this study was partly supported by the Hungarian Scientific Research Fund (OTKA) grant K101914. The authors also thank Venche Talgø from the Norwegian Institute for Agricultural and Environmental Research (Bioforsk) in Ås, Norway; Karin Rosendahl and Willem Man In' t Veld from the Plant Protection Service in Wageningen, the Netherlands; Sabine Werres from the Julius-Kühn-Institute in Braunschschweig, Germany; David Cooke from the James-Hutton-Institute in Dundee, UK; and Benoit Marçais from INRA Nancy, France, for providing isolates of $P$. fragariae, $P$. rubi, $P$. uniformis and P. $\mathrm{x}$ multiformis for comparative morphological analyses.

\section{References}

Ann PJ, Wong IT, Tsai JN, 2010. New records of Phytophthora diseases of aromatic crops in Taiwan. Plant Pathology Bulletin 19, 53-68.

Aragaki M, Uchida JY, 2001. Morphological distinctions between Phytophthora capsici and P. tropicalis sp. nov. Mycologia 93, 137-45.

Arentz F, Simpson JA, 1986. Distribution of Phytophthora cinnamomi in Papua New Guinea and notes on its origin. Transactions of the British Mycological Society 87, 289-95.

Balci Y, Balci S, Eggers J, MacDonald WL, Juzwik J, Long RP, Gottschalk KW, 2007. Phytophthora spp. associated with forest soils in eastern and north-central U.S. oak ecosystems. Plant Disease 91, 705-10.

This article is protected by copyright. All rights reserved. 
Bezuidenhout CM, Denman S, Kirk SA, Botha WJ, Mostert L, McLeod A, 2010. Phytophthora taxa associated with cultivated Agathosma, with emphasis on the P. citricola complex and $P$. capensis sp. nov. Persoonia 25, 32-49.

Brasier CM, 2008. The biosecurity threat to the UK and global environment from international trade in plants. Plant Pathology 57, 792-808.

Brasier CM, Vettraino AM, Chang TT, Vannini A, 2010. Phytophthora lateralis discovered in an old growth Chamaecyparis forest in Taiwan. Plant Pathology 59, 595-603.

Burgess TI, 2015. Molecular characterization of natural hybrids formed between five related indigenous Clade 6 Phytophthora species. PLoS ONE 10(8), e0134225. doi:10.1371/journal.pone.0134225.

Català S, Peréz-Sierra A, Abad-Campos P, 2015. The use of genus-specific amplicon pyrosequencing to assess Phytophthora species diversity using eDNA from soil and water in Northern Spain. PLoS ONE 10(3), e0119311.

Chang TT, Wang WW, Wang WY, 1996. Use of random amplified polymorphic DNA markers for the detection of genetic variation in Phytophthora cinnamomi in Taiwan. Botanical Bulletin Academia Sinica 37, 165-71.

Chang-Fu H, Chung-Fu S, 1994. Introduction to the flora of Taiwan, 1: geography, geology, climate, and soils. In: Flora of Taiwan Second Edition: 1-3. Editorial Committee of the Flora of Taiwan Second Edition, Taipei, Republic of China (http://tai2.ntu.edu.tw/ebook/ ebookpage.php?volume=1\&book=Fl.\%20Taiwan\%202nd\%20edit.\&page=1).

Chang-Fu H, Chung-Fu S, Kuoh-Cheng Y, 1994. Introduction to the flora of Taiwan, 3: floristics, phytogeography, and vegetation. In: Flora of Taiwan Second Edition: 7-18. Editorial Committee of the Flora of Taiwan Second Edition, Taipei, Republic of China (http://tai2.ntu.edu.tw/ebook/ ebookpage.php?book=Fl.\%20Taiwan\%202nd\%20edit.\&volume=1\&page=7).

Chung-Fu S, 1994. Introduction to the flora of Taiwan, 2: geotectonic evolution, paleogeography, and the origin of the flora. In: Flora of Taiwan Second Edition: 3-7. Editorial Committee of the Flora of Taiwan Second Edition, Taipei, Republic of China (http://tai2.ntu.edu.tw/ebook/ ebookpage.php?book=Fl.\%20Taiwan\%202nd\%20edit.\&volume=1\&page=3).

This article is protected by copyright. All rights reserved. 
Cooke DEL, Drenth A, Duncan JM, Wagels G, Brasier CM, 2000. A molecular phylogeny of Phytophthora and related Oomycetes. Fungal Genetics and Biology 30, 17-32.

Dobrowolski MP, Tommerup IC, Blakeman HD, 2003. Non-mendelian inheritance revealed in a genetic analysis of sexual progeny of Phytophthora cinnamomi with microsatellite markers. Fungal Genetics and Biology 35, 197-212.

Drenth A, Guest DI (Eds.), 2004. Diversity and management of Phytophthora in Southeast Asia. ACIAR Monograph 114. Australian Centre for International Agricultural Research, Canberra: 238 pp.

Erwin DC, Ribeiro OK, 1996. Phytophthora Diseases Worldwide. APS Press, St. Paul, Minnesota.

Gower DJ, Johnson KG, Richardson JE, Rosen BR, Rüber L, Williams ST, 2012. Biotic evolution and environmental change in Southeast Asia. The Systematics Association Special Volume 82. Cambridge University Press, New York, USA: 491 pp.

Hansen EM, Reeser PW, Sutton W, 2012. Phytophthora beyond agriculture. Annual Review of Phytopathology 50, 359-78.

Hardham AR, 2005. Phytophthora cinnamomi. Molecular Plant Pathology 6, 589-604.

Ho HH, 1990. Taiwan Phytophthora. Botanical Bulletin Academia Sinica 31, 89-106.

Ho HH, Lu JY, 1997. A synopsis of the occurrence and pathogenicity of Phytophthora species in mainland China. Mycopathologia 138, 143-61.

Huai WX, Tian G, Hansen EM, Zhao WX, Goheen EM, Grünwald NJ, Cheng C, 2013. Identification of Phytophthora species baited and isolated from forest soil and streams in northwestern Yunnan province, China. Forest Pathology 43, 87-103.

Hüberli D, Hardy GESt], White D, Williams N, Burgess TI, 2013. Fishing for Phytophthora from Western Australia's waterways: A distribution and diversity survey. Australasian Plant Pathology 42, 251-60.

Jung T, 2009. Beech decline in Central Europe driven by the interaction between Phytophthora infections and climatic extremes. Forest Pathology 39, 73-94.

Jung T, Burgess TI, 2009. Re-evaluation of Phytophthora citricola isolates from multiple woody hosts in Europe and North America reveals a new species, Phytophthora plurivora sp. nov. . Persoonia 22, 95-110.

This article is protected by copyright. All rights reserved. 
Jung T, Stukely MJC, Hardy GEStJ, White D, Paap T, Dunstan WA, Burgess TI, 2011. Multiple new Phytophthora species from ITS Clade 6 associated with natural ecosystems in Australia: evolutionary and ecological implications. Persoonia 26, 13-39.

Jung T, Vettraino AM, Cech TL, Vannini A, 2013. The impact of invasive Phytophthora species on European forests. In: Lamour K. (ed). Phytophthora: A global perspective. CABI, Wallingford, UK: 146-58.

Jung T, Orlikowski L, Henricot B, Abad-Campos P, Aday AG, Aguín Casal O, Bakonyi J, Cacciola SO, Cech T, Chavarriaga D, Corcobado T, Cravador A, Decourcelle T, Denton G, Diamandis S, Dogmus-Lehtijärvi HT, Franceschini A, Ginetti B, Green S, Glavendekić M, Hantula J, Hartmann G, Herrero M, Ivic D, Horta Jung M, Lilja A, Keca N, Kramarets V, Lyubenova A, Machado H, Magnano di San Lio G, Mansilla Vázquez PJ, Marçais B, Matsiakh I, Milenkovic I, Moricca S, Nagy ZÁ, Nechwatal J, Olsson C, Oszako T, Pane A, Paplomatas EJ, Pintos Varela C, Prospero S, Rial Martínez C, Rigling D, Robin C, Rytkönen A, Sánchez ME, Sanz Ros AV, Scanu B, Schlenzig A, Schumacher J, Slavov S, Solla A, Sousa E, Stenlid J, Talgø V, Tomic Z, Tsopelas P, Vannini A, Vettraino AM, Wenneker M, Woodward S, Peréz-Sierra A, 2015. Widespread Phytophthora infestations in European nurseries put forest, semi-natural and horticultural ecosystems at high risk of Phytophthora diseases. Forest Pathology 46, 134163. doi: 10.1111/efp.12239.

Ko WH, Chang HS, Su HJ, 1978. Isolates from Phytophthora cinnamomi from Taiwan as evidence for an Asian origin of the species. Transactions of the British Mycological Society 71, 496-99.

Ko WH, Wang SY, Ann PJ, 2006. The possible origin and relation of Phytophthora katsurae and P. heveae, discovered in a protected natural forest in Taiwan. Botanical Studies 47, 273-7.

Kroon LPNM, Bakker FT, van den Bosch GBM, Bonants PJM, Flier WG, 2004. Phylogenetic analysis of Phytophthora species based on mitochondrial and nuclear DNA sequences. Fungal Genetics and Biology 41, 766-82.

Man In' t Veld WAM, Rosendahl KCHM, van Rijswick PCJ, Meffert JP, Westenberg M, van de Vossenberg BTLH, Denton G, van Kuik FAJ, 2015. Phytophthora terminalis sp. nov. and Phytophthora occultans sp. nov., two invasive pathogens of ornamental plants in Europe. Mycologia 107, 54-65.

Martin FN, Tooley PW, 2003. Phylogenetic relationships among Phytophthora species inferred from sequence analysis of mitochondrially encoded cytochrome oxidase I and II genes. Mycologia 95, 269-84.

This article is protected by copyright. All rights reserved. 
Martin FN, Blair JE, Coffey MD. 2014. A combined mitochondrial and nuclear multilocus phylogeny of the genus Phytophthora. Fungal Genetics and Biology 66, 19-32.

Nagel JH, Gryzenhout M, Slippers B, Wingfield MJ, Hardy GEStJ, Stukely M, Burgess TI 2013.Characterization of Phytophthora hybrids from ITS clade 6 associated with riparian ecosystems in South Africa and Australia. Fungal Biology 117, 329-47.

Nagy ZÁ, Bakonyi J, Érsek T, 2003. Standard and Swedish variant types of the hybrid alder Phytophthora attacking alder in Hungary. Pest Management Science 59, 484-92.

Nechwatal J, Bakonyi J, Cacciola SO, Cooke DEL, Jung T, Nagy ZA, Vannini A, Vettraino AM, Brasier CM. 2013. The morphology, behaviour and molecular phylogeny of Phytophthora taxon Salixsoil and its redesignation as Phytophthora lacustris sp. nov. Plant Pathology 62, 355-69.

Oh E, Gryzenhout M, Wingfield BD, Wingfield MJ, Burgess TI, 2013. Surveys of soil and water reveal a goldmine of Phytophthora diversity in South African natural ecosystems. IMA Fungus 4 (1), 123-31.

Rahman MZ, Uematsu S, Takeuchi T, Shirai K, Ishiguro Y, Suga H, Kageyama K 2014. Two new species, Phytophthora nagaii sp. nov. and P. fragariaefolia sp. nov., causing serious diseases on rose and strawberry plants, respectively, in Japan. Journal of General Plant Pathology 80, 348-65.

Rands RD, 1922. Streepkanker van kaneel, veroorzaakt door Phytophthora cinnamomi n. sp. (stripe canker of cinnamon caused by Phytophthora cinnamomi n. sp.). Medeelingen van het Instituut voor Plantenziekten. No. 54: 60 pp.

Reeser PW, Sutton W, Hansen EM, Remigi P, Adams GC, 2011. Phytophthora species in forest streams in Oregon and Alaska. Mycologia 103, 22-35.

Reeser PW, Sutton W, Hansen EM. 2015. First Report of Phytophthora occultans causing root and collar rot on Ceanothus, Boxwood, Rhododendron, and other hosts in horticultural nurseries in Oregon, USA. Plant Disease 99, 1282.

Rizzo DM, Garbelotto M, Davidson JM, Slaugter GW, 2002. Phytophthora ramorum as the cause of extensive mortality of Quercus spp. and Lithocarpus densiflorus in California. Plant Disease 86, 205-14.

Scanu B, Hunter GC, Linaldeddu BT, Franceschini A, Maddau L, Jung T, Denman S, 2014. A taxonomic re-evaluation reveals that Phytophthora cinnamomi and P. cinnamomi var.

This article is protected by copyright. All rights reserved. 
parvispora are separate species. Forest Pathology 44, 1-20.

Shrestha SK, Zhou Y, Lamour K, 2013. Oomycetes baited from streams in Tennessee 2010-2012. Mycologia 105, 1516-23.

Vettraino AM, Brasier CM, Brown AV, Vannini A, 2011. Phytophthora himalsilva sp. nov. an unusually phenotypically variable species from a remote forest in Nepal. Fungal Biology 115, 275-87.

White TJ, Bruns T, Lee S, Taylor J, 1990. Amplification and direct sequencing of fungal ribosomal RNA genes for phylogenetics. In: Innes MA, Gelfand DH, Sninsky JJ, White TJ, eds. PCR Protocols: A Guide to Methods and Applications. San Diego, CA, USA: Academic Press, 31522.

Yang X, Hong C, 2013. Phytophthora virginiana sp. nov., a high-temperature tolerant species from irrigation water in Virginia. Mycotaxon 126, 167-76.

Zeng H-C, Ho H-H, Zheng F-C, 2009. A survey of Phytophthora species on Hainan Island of South China. Journal of Phytopathology 157, 33-9.

\section{Figure legends}

Fig. 1. Location of the 25 forest stands (F01-F25; black dots) and 25 riparian sites (R01-R25; blue triangles) included in the Phytophthora survey in Taiwan. For GPS coordinates see Tables 1 and 2 .

Fig. 2. Representative forest stands and rivers sampled in Taiwan; a. montane, temperate mixed coniferous forest F08 in Sheipa National Park; b. montane, temperate deciduous beech forest F04 at Taiping Mountain; c. montane, temperate, seasonally dry, deciduous broadleaved forest F12 in Tunyuan; d. subtropical evergreen Castanopsis-Machilus forest F02 in Fushan; e. subtropical evergreen lowland monsoon forest in the Pacific Coastal Range in Hualien County; f. subtropical evergreen broadleaved forest on Hengchun Peninsula; g. San-zhan River (R20) coming out of subtropical evergreen lowland monsoon forests and montane, temperate 
evergreen broadleved forests at Taroko National Park; h. baiting raft (arrow) floating in the tributary of Hapen River (R03) in the subtropical evergreen Castanopsis-Machilus forest F02 in Fushan. For GPS coordinates see Table 1; for location of sites see Figure 1.

Fig. 3. Disease symptoms of mature native trees in natural forest stands in Taiwan associated with presence of Phytophthora species in the rhizosphere; a. crown dieback of Castanopsis kawakami in the subtropical evergreen Castanopsis-Machilus forest F15 in Lenhuachih $(P$. cinnamomi A1 and A2, P. Castaneae); b-f. subtropical evergreen Castanopsis-Machilus forest F02 in Fushan (P. cinnamomi A1 and A2, P. castaneae); b and c. crown thinning and dieback of Diospyros morissiana (b) and Cinnamomum micranthum (c); d. healthy (white arrows), declining (black arrow) and dying (red arrow) trees of Castanopsis carlesii; e. crown thinning and dieback of $C$. carlesii; f. collar rot of $C$. carlesii with tarry spots on the outer bark; g. crown thinning and dieback of Quercus sessilifolia (black arrows) and Quercus morii (white arrow) in the montane, temperate evergreen Quercus forest F09 in Sheipa National Park (P. cinnamomi A1).

Fig. 4. a-d. Symptoms on root systems in the subtropical evergreen Castanopsis-Machilus forest F02 in Fushan infested by P. cinnamomi A1 and A2 and by P. castaneae; a. dieback (arrow) of woody root of Castanopsis carlesii; b-d. small woody roots of C. carlesii (b), Cinnamomum micranthum (c) and Diospyros morissiana (d) with severe losses of lateral roots and fine roots; ef. symptomatic roots of Quercus morii in the montane, temperate evergreen Quercus forest F09 in Sheipa National Park infested by P. cinnamomi A1; e. small woody roots with severe losses of lateral roots and fine roots; f. coarse root with open callussing lesion.

\section{Supplementary Tables}

Table 1S. GenBank accession numbers of ITS and partial cox1 sequences generated in this study for representative Phytophthora isolates from Taiwanese forests and rivers and isolates from related Phytophthora species used for comparisons.

This article is protected by copyright. All rights reserved. 
Table 2S. Polymorphic nucleotides from aligned ITS sequence data showing the variation between eight haplotypes (H) of P. cinnamomi from Taiwanese forests and the ex-type (T) isolate of $P$. cinnamomi from Sumatra. Grey shading denotes no data available.

Table 3S. Polymorphic nucleotides from aligned ITS sequence data showing the variation between selected isolates of $P$. attenuata nom. prov., P. flexuosa nom. prov., P. formosa nom. prov., $P$. intricata nom. prov., $P$. x heterohybrida nom. prov. and $P . \mathrm{x}$ incrassata nom. prov. from Taiwan and ex-type (T) or key isolates of related Phytophthora species from Clade 7a.

Table 4S. Polymorphic nucleotides from aligned partial cox1 sequence data showing the variation between selected isolates of $P$. attenuata nom. prov., P. flexuosa nom. prov., P. formosa nom. prov., P. intricata nom. prov., P. x heterohybrida nom. prov. and P. x incrassata nom. prov. from Taiwan and ex-type (T) or key isolates of other Phytophthora species from Clade 7a.

Table 5S. Polymorphic nucleotides from aligned ITS sequence data showing the variation between selected isolates of $P$. sp. $\mathrm{x}$ botryosa-like, $P$. sp. x meadii-like and $P$. sp. occultans-like from Taiwan and ex-type (T) or key isolates of related Phytophthora species from Clade 2a. Grey shading denotes no data available.

Table 6S. Polymorphic nucleotides from aligned partial $\operatorname{cox} 1$ sequence data showing the variation between selected isolates of $P$. sp. x botryosa-like, $P$. sp. x meadii-like and $P$. sp. occultans-like from Taiwan and ex-type (T) or key isolates of related Phytophthora species from Clade 2a. Grey shading denotes no data available.

Table 7S. Polymorphic nucleotides from aligned ITS sequence data showing the variation between selected isolates of $P$. sp. x Kunnunara-like, $P$. sp. x virginiana-like $1, P$. sp. $\mathrm{x}$ virginianalike 2 and $P$. sp. x virginiana-like 3 from Taiwan and ex-type (T) or key isolates of related Phytophthora species from Clade 9. Grey shading denotes no data available.

Table 8S. Polymorphic nucleotides from aligned partial $\operatorname{cox} 1$ sequence data showing the variation between selected isolates of $P$. sp. x Kunnunara-like, $P . \mathrm{sp} . \mathrm{x}$ virginiana-like $1, P . \mathrm{sp} . \mathrm{x}$ virginiana-like 2 and $P$. sp. x virginiana-like 3 from Taiwan and ex-type (T) or key isolates of related Phytophthora species from Clade 9. Grey shading denotes no data available.

This article is protected by copyright. All rights reserved. 
Table 1: Location, altitude, geological substrate and vegetation of 25 forest sites sampled in Taiwan, sampled tree species and Phytophthora taxa isolated.

\begin{tabular}{|c|c|c|c|c|c|c|c|}
\hline $\begin{array}{l}\text { Site } \\
\text { no. }\end{array}$ & $\begin{array}{l}\text { GPS } \\
\text { coordinates }\end{array}$ & $\begin{array}{l}\text { Altitude } \\
\text { (m a.s.l) }\end{array}$ & Location & $\begin{array}{l}\text { Geological } \\
\text { substrate }\end{array}$ & Vegetation & $\begin{array}{l}\text { Sampled tree species (no. of } \\
\text { Phytophthora- } \\
\text { positive/sampled trees) }\end{array}$ & $\begin{array}{l}\text { Phytophthora spp. (no. of } \\
\text { positive samples) a, b }\end{array}$ \\
\hline F01 & $\begin{array}{l}\text { N24 } 45.892 \\
\text { E121 } 35.195\end{array}$ & 653 & Fushan, Yilan county & Shale & $\begin{array}{l}\text { Fagaceae arboretum } \\
\text { established in the } \\
\text { subtropical evergreen } \\
\text { Castanopsis-Machilus } \\
\text { forest F02 }\end{array}$ & $\begin{array}{l}\text { Quercus glandulifera }(2 / 2) \\
\text { Quercus glauca }(1 / 1) \\
\text { Quercus stenophyloides }(1 / 1) \\
\text { Quercus tarokoensis }(4 / 4) \\
\text { Quercus tatakaensis }(0 / 1) \\
\text { Quercus variabilis }(0 / 1) \\
\text { Rhododendron sp. }(0 / 1)\end{array}$ & $\begin{array}{l}\text { CIN A2 (1), FOR (2) } \\
\text { CAS (1), CIN A1 (1) } \\
\text { CIN A1 (1), CIN A2 (1) } \\
\text { CIN A2ho (1), CIP (1), INT (4) } \\
- \\
- \\
-\end{array}$ \\
\hline F02 & $\begin{array}{l}\text { N24 } 45.585 \\
\text { E121 } 34.929\end{array}$ & 698 & Fushan, Yilan county & Shale & $\begin{array}{l}\text { Subtropical evergreen } \\
\text { Castanopsis-Machilus } \\
\text { forest }\end{array}$ & $\begin{array}{l}\text { Castanopsis carlesii }(9 / 13) \\
\text { Cinnamomum micranthum } \\
(3 / 3) \text { Diospyros morissiana } \\
(4 / 4) \\
\text { Lithocarpus hancei }(1 / 1) \\
\text { Machilus thunbergii }(2 / 2)\end{array}$ & $\begin{array}{l}\text { CAS (5), CIN A1 (2), CIN A2 } \\
(3) \text { c } \\
\text { CAS (1), CIN A2 (3) } \\
\text { CIN A1 (1), CIN A2 (3) } \\
\text { CAS (1) } \\
\text { CIN A1 }(2 / 2)\end{array}$ \\
\hline F03 & $\begin{array}{l}\text { N24 } 32.000 \\
\text { E121 22.000 }\end{array}$ & 1902 & $\begin{array}{l}\text { Chilan mountain, } \\
\text { Yilan county }\end{array}$ & Argillite & $\begin{array}{l}\text { Montane, temperate } \\
\text { mixed coniferous forest }\end{array}$ & Chamaecyparis obtusa $(2 / 2)$ & CHL (2), CIN A1 (1) \\
\hline F04 & $\begin{array}{l}\text { N24 } 30.348 \\
\text { E121 37.856 }\end{array}$ & 1741 & $\begin{array}{l}\text { Taiping mountain, } \\
\text { Yilan county }\end{array}$ & Slate & $\begin{array}{l}\text { Montane, temperate } \\
\text { deciduous beech forest }\end{array}$ & Fagus hayatae (8/9) & CAS (1), CIN A1 (8), FLE (3) d \\
\hline F05 & $\begin{array}{l}\text { N } 2430.240, \\
\text { E } 121 \\
37.346 \\
\end{array}$ & 1967 & $\begin{array}{l}\text { Taiping mountain, } \\
\text { Yilan county }\end{array}$ & Slate & $\begin{array}{l}\text { Montane, temperate } \\
\text { mixed coniferous forest }\end{array}$ & C. obtusa (3/4) & CHL (2), CIN A1 (2) \\
\hline F06 & $\begin{array}{l}\text { N24 } 29.687 \\
\text { E121 32.108 }\end{array}$ & 1973 & $\begin{array}{l}\text { Taiping mountain, } \\
\text { Yilan county }\end{array}$ & $\begin{array}{l}\text { Argillite and } \\
\text { slate }\end{array}$ & $\begin{array}{l}\text { Montane, temperate } \\
\text { mixed coniferous forest }\end{array}$ & $\begin{array}{l}\text { C. obtusa }(5 / 5) \\
\text { Rhododendron sp. + Juniperus } \\
\text { sp., mixed sample }(0 / 1)\end{array}$ & ${ }_{-}^{C I N ~ A 1 ~(5) ~}{ }^{d}$ \\
\hline F07 & $\begin{array}{l}\text { N24 } 52.611 \\
\text { E120 58.255 }\end{array}$ & 110 & $\begin{array}{l}\text { Hsingfeng } \\
\text { Township, Hsinchu } \\
\text { County }\end{array}$ & $\begin{array}{l}\text { Alluvial } \\
\text { sediments }\end{array}$ & $\begin{array}{l}\text { Subtropical, seasonally } \\
\text { dry, partially deciduous } \\
\text { broadleaved forest }\end{array}$ & $\begin{array}{l}\text { Quercus aliena }(0 / 4) \\
\text { Q. variabilis }(1 / 4) \\
\text { Cinnamomum camphora }(1 / 1)\end{array}$ & $\begin{array}{l}- \\
\operatorname{HEV}(1) \\
\operatorname{HEV}(1)\end{array}$ \\
\hline F08 & $\begin{array}{l}\text { N24 } 30.354 \\
\text { E121 } 5.568\end{array}$ & 2182 & $\begin{array}{l}\text { Sheipa National } \\
\text { Park, Hsinchu } \\
\text { County }\end{array}$ & Shale & $\begin{array}{l}\text { Montane, temperate } \\
\text { mixed coniferous forest }\end{array}$ & $\begin{array}{l}\text { Chamaecyparis formosensis } \\
(3 / 5) \\
\text { Taiwania cryptomeroides }(0 / 1) \\
\text { Rhododendron sp. }(0 / 2)\end{array}$ & $\begin{array}{l}\text { ATT (3), CAS (1) e } \\
- \\
-\end{array}$ \\
\hline
\end{tabular}

This article is protected by copyright. All rights reserved. 


\begin{tabular}{|c|c|c|c|c|c|c|c|}
\hline $\begin{array}{l}\text { Site } \\
\text { no. }\end{array}$ & $\begin{array}{l}\text { GPS } \\
\text { coordinates }\end{array}$ & $\begin{array}{l}\text { Altitude } \\
\text { (m a.s.l) }\end{array}$ & Location & $\begin{array}{l}\text { Geological } \\
\text { substrate }\end{array}$ & Vegetation & $\begin{array}{l}\text { Sampled tree species (no. of } \\
\text { Phytophthora- } \\
\text { positive/sampled trees) }\end{array}$ & $\begin{array}{l}\text { Phytophthora spp. (no. of } \\
\text { positive samples) a, b }\end{array}$ \\
\hline F09 & $\begin{array}{l}\text { N24 } 30.224 \\
\text { E121 } 5.403\end{array}$ & 2287 & $\begin{array}{l}\text { Sheipa National } \\
\text { Park, Hsinchu } \\
\text { County }\end{array}$ & Shale & $\begin{array}{l}\text { Montane, temperate } \\
\text { evergreen Quercus forest }\end{array}$ & $\begin{array}{l}\text { Quercus morii }(1 / 1) \\
\text { Quercus sessilifolia }(2 / 2)\end{array}$ & $\begin{array}{l}\text { CIN A1 (1) } \\
\text { CIN A1 (2) }\end{array}$ \\
\hline F10 & $\begin{array}{l}\text { N24 } 30.045 \\
\text { E121 } 6.595\end{array}$ & 2174 & $\begin{array}{l}\text { Sheipa National } \\
\text { Park, Hsinchu } \\
\text { County }\end{array}$ & Shale & $\begin{array}{l}\text { Montane, temperate } \\
\text { mixed coniferous forest }\end{array}$ & C. carlesii $(2 / 2)$ & ATT (2) \\
\hline F11 & $\begin{array}{l}\text { N24 3.051 } \\
\text { E121 } 12.925\end{array}$ & 2023 & $\begin{array}{l}\text { Tunyuan, Nantou } \\
\text { County }\end{array}$ & $\begin{array}{l}\text { Argillite and } \\
\text { slate }\end{array}$ & $\begin{array}{l}\text { Montane, temperate, } \\
\text { seasonally dry, } \\
\text { deciduous Quercus - } \\
\text { Pinus forest }\end{array}$ & Q. variabilis $(2 / 5)$ & CIN A1 (1), CIT (2) \\
\hline F12 & $\begin{array}{l}\text { N24 } 2.511 \\
\text { E121 12.734 }\end{array}$ & 1848 & $\begin{array}{l}\text { Tunyuan, Nantou } \\
\text { County }\end{array}$ & $\begin{array}{l}\text { Argillite and } \\
\text { slate }\end{array}$ & $\begin{array}{l}\text { Montane, temperate, } \\
\text { seasonally dry, } \\
\text { deciduous broadleaved } \\
\text { forest }\end{array}$ & $\begin{array}{l}\text { Alnus formosensis }(1 / 1) \\
\text { Carpinus kawakami }(0 / 1) \\
\text { Liquidambar formosensis }(1 / 1) \\
\text { Q. variabilis }(0 / 2)\end{array}$ & $\begin{array}{l}\text { PLU (1) } \\
- \\
\text { PLU (1) } \\
-\end{array}$ \\
\hline F13 & $\begin{array}{l}\text { N24 } 1.501 \\
\text { E121 } 9.169\end{array}$ & 1343 & $\begin{array}{l}\text { Huagang Mountain, } \\
\text { Nantou County }\end{array}$ & $\begin{array}{l}\text { Argillite and } \\
\text { slate }\end{array}$ & $\begin{array}{l}\text { Montane, warm- } \\
\text { temperate, seasonally } \\
\text { dry, partially deciduous } \\
\text { Quercus forest }\end{array}$ & $\begin{array}{l}\text { Q. glauca }(1 / 2) \\
\text { Q. variabilis }(4 / 7)\end{array}$ & $\begin{array}{l}\text { non-culturable Phytophthora } \\
\text { species (1) } \\
\text { non-culturable Phytophthora } \\
\text { species (3) }{ }^{\mathrm{f}}\end{array}$ \\
\hline F14 & $\begin{array}{l}\text { N24 } 1.599 \\
\text { E121 } 9.382\end{array}$ & 1266 & $\begin{array}{l}\text { Huagang Mountain, } \\
\text { Nantou County }\end{array}$ & $\begin{array}{l}\text { Argillite and } \\
\text { slate }\end{array}$ & $\begin{array}{l}\text { Montane, warm- } \\
\text { temperate, seasonally } \\
\text { dry, deciduous Quercus } \\
\text { forest }\end{array}$ & Q. variabilis (1/4) & CIN A1 (1) \\
\hline F15 & $\begin{array}{l}\text { N23 } 55.149 \\
\text { E120 52.996 }\end{array}$ & 733 & $\begin{array}{l}\text { Lenhuachih, Nantou } \\
\text { County }\end{array}$ & $\begin{array}{l}\text { Sandstone and } \\
\text { shale }\end{array}$ & $\begin{array}{l}\text { Subtropical evergreen } \\
\text { Castanopsis-Machilus } \\
\text { forest }\end{array}$ & $\begin{array}{l}\text { Machilus kusanoi }(2 / 3) \\
\text { M. thunbergii }(3 / 3) \\
\text { Castanopsis kawakami }(6 / 6) \\
\text { Castanopsis uraiana }(2 / 3) \\
\text { Araucaria cunninghamii }(2 / 2)\end{array}$ & $\begin{array}{l}\text { CIN A1 (2), CIN A2 (1) }{ }^{c} \\
\text { CAS (1), CIN A2 (2) } \\
\text { CIN A1 (3), CIN A2 (5) }{ }^{c} \\
\text { CIN A1 (1), CIN A2 (2) } \\
\text { FOR (2) }\end{array}$ \\
\hline F16 & $\begin{array}{l}\text { N24 } 12.545 \\
\text { E121 } 40.244\end{array}$ & 210 & $\begin{array}{l}\text { Taroko National } \\
\text { Park, Hualien } \\
\text { County }\end{array}$ & $\begin{array}{l}\text { Metamorphosed } \\
\text { limestone }\end{array}$ & $\begin{array}{l}\text { Subtropical evergreen } \\
\text { lowland monsoon forest }\end{array}$ & Glochidion philippicum (1/1) & $\operatorname{HEV~}(1)^{c}$ \\
\hline F17 & $\begin{array}{l}\text { N24 9.563 } \\
\text { E12136.705 }\end{array}$ & 108 & $\begin{array}{l}\text { Taroko National } \\
\text { Park, Hualien } \\
\text { County }\end{array}$ & $\begin{array}{l}\text { Metamorphosed } \\
\text { limestone }\end{array}$ & $\begin{array}{l}\text { Subtropical evergreen } \\
\text { lowland monsoon forest }\end{array}$ & $\begin{array}{l}\text { Cinnamomum camphora, Styrax } \\
\text { suberifolia and G. philippicum, } \\
\text { mixed samples }(2 / 2)\end{array}$ & BOT (2), KUN (1) ${ }^{c}$ \\
\hline
\end{tabular}

This article is protected by copyright. All rights reserved. 


\begin{tabular}{|c|c|c|c|c|c|c|c|}
\hline $\begin{array}{l}\text { Site } \\
\text { no. }\end{array}$ & $\begin{array}{l}\text { GPS } \\
\text { coordinates }\end{array}$ & $\begin{array}{l}\text { Altitude } \\
\text { (m a.s.l) }\end{array}$ & Location & $\begin{array}{l}\text { Geological } \\
\text { substrate }\end{array}$ & Vegetation & $\begin{array}{l}\text { Sampled tree species (no. of } \\
\text { Phytophthora- } \\
\text { positive/sampled trees) }\end{array}$ & $\begin{array}{l}\text { Phytophthora spp. (no. of } \\
\text { positive samples) a, b }\end{array}$ \\
\hline F18 & $\begin{array}{l}\text { N23 } 30.276 \\
\text { E121 26.134 } \\
\end{array}$ & 102 & $\begin{array}{l}\text { Pacific coastal range, } \\
\text { Hualien County }\end{array}$ & $\begin{array}{l}\text { Volcaniclastic } \\
\text { sediments } \\
\end{array}$ & $\begin{array}{l}\text { Subtropical evergreen } \\
\text { lowland monsoon forest }\end{array}$ & $\begin{array}{l}\text { C. camphora }(3 / 5) \\
\text { S. suberifolia }(2 / 2)\end{array}$ & $\begin{array}{l}\text { BOT (1), HEV (2), MEA (1) c } \\
\text { MEA (2) }\end{array}$ \\
\hline F19 & $\begin{array}{lll}\text { N23 } & 14.320 \\
\text { E121 } & 19.165 \\
\end{array}$ & 671 & $\begin{array}{l}\text { Pacific coastal range, } \\
\text { Taitung County }\end{array}$ & Igneous tuff & $\begin{array}{l}\text { Subtropical evergreen } \\
\text { lowland monsoon forest }\end{array}$ & $\begin{array}{l}\text { Trema orientalis }(1 / 1) \\
\text { Morus australis }(0 / 1)\end{array}$ & $\begin{array}{l}\text { MEA (1) } \\
-\end{array}$ \\
\hline F20 & $\begin{array}{l}\text { N22 } 14.320 \\
\text { E120 51.455 }\end{array}$ & 440 & $\begin{array}{l}\text { Hengchun } \\
\text { Peninsula, Pingtun } \\
\text { County }\end{array}$ & $\begin{array}{l}\text { Sandstone and } \\
\text { shale }\end{array}$ & $\begin{array}{l}\text { Subtropical evergreen } \\
\text { broadleaved forest }\end{array}$ & $\begin{array}{l}\text { Lithocarpus shinsuiensis }(1 / 1) \\
\text { Engelhardia roxbhurghiana } \\
(1 / 1)\end{array}$ & $\begin{array}{l}\text { CAS (1), CIN A2ho (1) } \\
\text { CIN A2ho (1) }\end{array}$ \\
\hline F21 & $\begin{array}{l}\text { N22 } 12.659 \\
\text { E120 51.876 }\end{array}$ & 361 & $\begin{array}{l}\text { Hengchun } \\
\text { Peninsula, Pingtun } \\
\text { County } \\
\end{array}$ & $\begin{array}{l}\text { Sandstone and } \\
\text { shale }\end{array}$ & $\begin{array}{l}\text { Subtropical evergreen } \\
\text { broadleaved forest }\end{array}$ & $\begin{array}{l}\text { M. kusanoi }(0 / 1) \\
\text { Zelkova serrata }(1 / 1)\end{array}$ & $\begin{array}{l}-\mathrm{c} \\
\text { PAL A1 (1) }\end{array}$ \\
\hline F22 & $\begin{array}{l}\text { N22 } 9.271 \\
\text { E120 50.320 }\end{array}$ & 497 & $\begin{array}{l}\text { Hengchun } \\
\text { Peninsula, Pingtun } \\
\text { County }\end{array}$ & $\begin{array}{l}\text { Sandstone and } \\
\text { shale }\end{array}$ & $\begin{array}{l}\text { Subtropical evergreen } \\
\text { swamp forest }\end{array}$ & Glochidion rubrum (1/1) & $\begin{array}{l}\text { CIN A1 (1), PAR A1 (1), PLS } \\
\text { (1) }\end{array}$ \\
\hline F23 & $\begin{array}{l}\text { N22 } 9.047 \\
\text { E120 50.504 }\end{array}$ & 468 & $\begin{array}{l}\text { Hengchun } \\
\text { Peninsula, Pingtun } \\
\text { County }\end{array}$ & $\begin{array}{l}\text { Sandstone and } \\
\text { shale }\end{array}$ & $\begin{array}{l}\text { Subtropical evergreen } \\
\text { broadleaved forest }\end{array}$ & Castanopsis indica (2/2) & CIN A1 (2), CIN A2ho (1) \\
\hline F24 & $\begin{array}{l}\text { N22 } 9.024 \\
\text { E120 } 50.519\end{array}$ & 465 & $\begin{array}{l}\text { Hengchun } \\
\text { Peninsula, Pingtun } \\
\text { County }\end{array}$ & $\begin{array}{l}\text { Sandstone and } \\
\text { shale }\end{array}$ & $\begin{array}{l}\text { Subtropical evergreen } \\
\text { broadleaved forest }\end{array}$ & $\begin{array}{l}\text { Quercus championii }(3 / 3) \\
\text { Quercus longinux }(1 / 1)\end{array}$ & $\begin{array}{l}\text { CIN A1 (2), CIN A2ho (2) } \\
\text { CIN A1 (1) }\end{array}$ \\
\hline F25 & $\begin{array}{l}\text { N22 } 8.435 \\
\text { E120 51.254 }\end{array}$ & 365 & $\begin{array}{l}\text { Hengchun } \\
\text { Peninsula, Pingtun } \\
\text { County }\end{array}$ & $\begin{array}{l}\text { Sandstone and } \\
\text { shale }\end{array}$ & $\begin{array}{l}\text { Subtropical evergreen } \\
\text { broadleaved forest }\end{array}$ & Castanopsis faberi (4/4) & $\begin{array}{l}\text { CIN A1 (4), CIN A2 (1), CIN } \\
\text { A2ho (2), HEV (1) }\end{array}$ \\
\hline
\end{tabular}

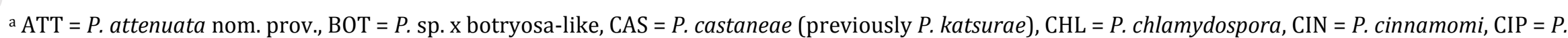
citrophthora, $\mathrm{CIT}=P$. citricola $\mathrm{VII}, \mathrm{FLE}=P$. flexuosa nom. prov., $\mathrm{FOR}=P$. formosa nom. prov., $\mathrm{HEV}=P$. heveae, $\mathrm{INT}=P$. intricata nom. prov., $\mathrm{KUN}=P . \mathrm{sp} . \mathrm{X}$

Kunnunara-like, $\mathrm{MEA}=$ P. sp. $\mathrm{x}$ meadii-like, $\mathrm{PAL}=$ P. palmivora, $\mathrm{PAR}=$ P. parvispora, $\mathrm{PLS}=$ P. sp. palustris, $\mathrm{PLU}=$ P. plurivora .

b Mating types: A1 = forming oogonia only in dual cultures with A2 tester strains; A2 = forming oogonia only in dual cultures with A1 tester strains; A2ho = forming oogonia in both dual cultures with A1 tester strains and in ageing single cultures.

c Phytopythium vexans also isolated.

d Elongisporangium undulatum also isolated.

e Elongisporangium anandrum also isolated.

${ }^{\mathrm{f}}$ Non-culturable Phytophthora species abundantly forming papillate and bi-papillate, persistent sporangia on $Q$. variabilis baiting leaves but not growing after plating them on PARPNH and PDA.

This article is protected by copyright. All rights reserved. 
Table 2: Location and altitude of the 25 riparian sites sampled in Taiwan and Phytophthora taxa isolated.

\begin{tabular}{|c|c|c|c|c|c|}
\hline Site no. & $\begin{array}{l}\text { GPS } \\
\text { coordinates }\end{array}$ & $\begin{array}{l}\text { Altitude } \\
\text { ( } \mathrm{m} \text { a.s.l) }\end{array}$ & River, county & Location of catchment & $\begin{array}{l}\text { Phytophthora spp. (no. of positive } \\
\text { samples) a, b }\end{array}$ \\
\hline R01 & $\begin{array}{l}\text { N25 } 1.197 \\
\text { E121 } 30.371\end{array}$ & 6 & $\begin{array}{l}\text { Xin-dian River, Taipei } \\
\text { City }\end{array}$ & $\begin{array}{l}\text { Hsueshan Range, northern-most part } \\
\text { of Western Foothills and Taipei Basin }\end{array}$ & KUN, VIR2, VIR3 \\
\hline R02 & $\begin{array}{l}\text { N24 } 56.828 \\
\text { E121 } 42.383\end{array}$ & 358 & $\begin{array}{l}\text { Tributary of Bei-shih } \\
\text { River, Pinglin Town- } \\
\text { ship, New Taipei City }\end{array}$ & $\begin{array}{l}\text { Northernmost part of Western } \\
\text { Foothills }\end{array}$ & CAP, KUN, OCC \\
\hline R03 & $\begin{array}{l}\text { N24 } 45.655 \\
\text { E12134.933 }\end{array}$ & 652 & $\begin{array}{l}\text { Tributary of Ha-pen } \\
\text { River, Fushan, New } \\
\text { Taipei City c }\end{array}$ & Northern part of Hsueshan Range & $\begin{array}{l}\text { CAP, FOR, FRS, INC A2, HET A1, HET } \\
\text { A2, HET A1/A2, OCC }\end{array}$ \\
\hline R04 & $\begin{array}{l}\text { N24 } 45.449 \\
\text { E12134.781 } \\
\end{array}$ & 644 & $\begin{array}{l}\text { Ha-pen River, Fushan, } \\
\text { New Taipei Cityd }\end{array}$ & Northern part of Hsueshan Range & HET A1, HET A2 \\
\hline R05 & $\begin{array}{l}\text { N24 45.510 } \\
\text { E12137.360 }\end{array}$ & 523 & $\begin{array}{l}\text { Cu-keng River, Yilan } \\
\text { County e }\end{array}$ & Northern part of Hsueshan Range & CHL, FRS, HET A1, HET A2, OCC \\
\hline R06 & $\begin{array}{l}\text { N24 45.032 } \\
\text { E12139.986 }\end{array}$ & 101 & $\begin{array}{l}\text { Wu-shi Creek, Yilan } \\
\text { County }\end{array}$ & Northern part of Hsueshan Range & - \\
\hline R07 & $\begin{array}{l}\text { N24 } 22.742 \\
\text { E120 51.856 }\end{array}$ & 298 & $\begin{array}{l}\text { Hou-long River, Miaoli } \\
\text { County }\end{array}$ & Western Foothills & INS, VIR1 \\
\hline R08 & $\begin{array}{l}\text { N24 } 20.917 \\
\text { E120 49.495 }\end{array}$ & 300 & $\begin{array}{l}\text { Xiao-keng River, Miaoli } \\
\text { County }\end{array}$ & Western Foothills & INS, VIR1, VIR2 \\
\hline R09 & $\begin{array}{l}\text { N24 } 18.536 \\
\text { E120 49.120 }\end{array}$ & 329 & $\begin{array}{l}\text { Da-an River, Taichung } \\
\text { County }\end{array}$ & $\begin{array}{l}\text { Hsueshan Range (Sheipa National } \\
\text { Park) and Western Foothills }\end{array}$ & INS, KUN, VIR1, VIR2, VIR3 \\
\hline R10 & $\begin{array}{l}\text { N24 17.263 } \\
\text { E120 48.067 }\end{array}$ & 307 & $\begin{array}{l}\text { Sha-lian River, Taichung } \\
\text { County }\end{array}$ & Western Foothills & Phytophthora sp. ${ }^{\mathrm{f}}$ \\
\hline R11 & $\begin{array}{l}\text { N24 } 9.894 \\
\text { E120 50.070 }\end{array}$ & 483 & $\begin{array}{l}\text { Tributary } 1 \text { of Da-jia } \\
\text { River, Taichung County }\end{array}$ & Western Foothills & PAR A1, TR0 A1 \\
\hline $\mathrm{R} 12$ & $\begin{array}{l}\text { N24 } 9.286 \\
\text { E120 51.487 }\end{array}$ & 520 & $\begin{array}{l}\text { Tributary } 2 \text { of Da-jia } \\
\text { River, Taichung County }\end{array}$ & Western Foothills & KUN, TRO A1 g \\
\hline $\mathrm{R} 13$ & $\begin{array}{l}\text { N24 } 9.530 \\
\text { E120 51.986 }\end{array}$ & 537 & $\begin{array}{l}\text { Ma-zhu-keng River, } \\
\text { Taichung County }\end{array}$ & Western Foothills & PAR A1 \\
\hline R14 & $\begin{array}{l}\text { N24 } 7.465 \\
\text { E120 52.577 } \\
\end{array}$ & 570 & $\begin{array}{l}\text { Er-guei River, Taichung } \\
\text { County }\end{array}$ & $\begin{array}{l}\text { Hsueshan Range and Western } \\
\text { Foothills }\end{array}$ & INS, KUN \\
\hline $\mathrm{R} 15$ & $\begin{array}{l}\text { N24 3.055 } \\
\text { E120 56.101 }\end{array}$ & 517 & $\begin{array}{l}\text { Tributary of Bei-gang } \\
\text { River, Taichung County }\end{array}$ & Hsueshan Range & - \\
\hline R16 & $\begin{array}{l}\text { N23 55.111 } \\
\text { E120 53.062 }\end{array}$ & 693 & $\begin{array}{l}\text { Hou-xi Creek, Nantou } \\
\text { County h }\end{array}$ & Hsueshan Range & - \\
\hline R17 & $\begin{array}{l}\text { N23 } 53.085 \\
\text { E120 53.491 }\end{array}$ & 564 & $\begin{array}{l}\text { Shui-she-shui-wei River, } \\
\text { Nantou County }\end{array}$ & Hsueshan Range & INS, KUN, PAR A1, VIR2 \\
\hline R18 & $\begin{array}{l}\text { N24 } 12.545 \\
\text { E121 } 40.244\end{array}$ & 210 & $\begin{array}{l}\text { Xiao-Qingshui Creek, } \\
\text { Hualien County i }\end{array}$ & $\begin{array}{l}\text { Central Mountain Ridge and Eastern } \\
\text { Taiwan Schist Range (Taroko National } \\
\text { Park) }\end{array}$ & BOT, MEA, VIR3 \\
\hline R19 & $\begin{array}{l}\text { N24 9.434 } \\
\text { E12137.079 }\end{array}$ & 54 & $\begin{array}{l}\text { Lee-wu River, Hualien } \\
\text { County }\end{array}$ & $\begin{array}{l}\text { Central Mountain Ridge and Eastern } \\
\text { Taiwan Schist Range (Taroko National } \\
\text { Park) }\end{array}$ & $-j$ \\
\hline $\mathrm{R} 20$ & $\begin{array}{l}\text { N24 } 6.217 \\
\text { E121 } 36.202\end{array}$ & 34 & $\begin{array}{l}\text { San-zhan River, Hualien } \\
\text { County }\end{array}$ & $\begin{array}{l}\text { Central Mountain Ridge and Eastern } \\
\text { Taiwan Schist Range (Taroko National } \\
\text { Park) }\end{array}$ & INS, KUN, VIR1, VIR2, VIR3 \\
\hline $\mathrm{R} 21$ & $\begin{array}{l}\text { N23 } 58.07 \\
\text { E121 } 29.472\end{array}$ & 147 & $\begin{array}{l}\text { Mu-gua River, Hualien } \\
\text { County }\end{array}$ & $\begin{array}{l}\text { Central Mountain Ridge and Eastern } \\
\text { Taiwan Schist Range }\end{array}$ & KUN \\
\hline $\mathrm{R} 22$ & $\begin{array}{l}\text { N23 } 41.220 \\
\text { E121 } 24.414\end{array}$ & 176 & $\begin{array}{l}\text { Ma-tai-an River, Hualien } \\
\text { County }\end{array}$ & Eastern Taiwan Schist Range & $-j$ \\
\hline $\mathrm{R} 23$ & $\begin{array}{l}\text { N23 39.670 } \\
\text { E121 25.157 }\end{array}$ & 122 & $\begin{array}{l}\text { Guang-fu River, Hualien } \\
\text { County }\end{array}$ & Eastern Taiwan Schist Range & INS, VIR1, VIR2, VIR3 \\
\hline $\mathrm{R} 24$ & $\begin{array}{l}\text { N23 } 33.302 \\
\text { E121 } 22.613\end{array}$ & 136 & $\begin{array}{l}\text { Fu-yuan River, Hualien } \\
\text { County }\end{array}$ & Eastern Taiwan Schist Range & KUN, VIR2 \\
\hline R25 & $\begin{array}{l}\text { N23 } 18.584 \\
\text { E121 } 15.312\end{array}$ & 223 & $\begin{array}{l}\text { La-ku-la-ku River, } \\
\text { Hualien County }\end{array}$ & $\begin{array}{l}\text { Central Mountain Ridge and Eastern } \\
\text { Taiwan Schist Range (Yushan National } \\
\text { Park) }\end{array}$ & $-j$ \\
\hline
\end{tabular}

This article is protected by copyright. All rights reserved. 
a BOT $=P$. sp. $\mathrm{x}$ botryosa-like, $\mathrm{CAP}=P$. capensis, $\mathrm{CHL}=P$. chlamydospora, $\mathrm{FOR}=$ Phytophthora formosa nom. prov., FRS $=P$. sp. forestsoil-like, INC $=P$. $\mathrm{x}$ incrassata nom. prov., HET $=P$. $\mathrm{x}$ heterohybrida nom. prov., INS $=P$. sp. $\mathrm{x}$ insolita-like, KUN $=P . \mathrm{sp} . \mathrm{x}$ Kunnunara-like, $\mathrm{MEA}=P . \mathrm{sp} . \mathrm{x}$ meadii-like, $\mathrm{OCC}=P$. sp. occultans-like, $\mathrm{PAR}=P$. parvispora, $\mathrm{TRO}=P$. tropicalis, $\mathrm{VIR} 1=P . \mathrm{sp} . \mathrm{x}$ virginiana-like $1, \mathrm{VIR} 2=P$. sp. $\mathrm{x}$ virginiana-like 2 , VIR3 $=P$. sp. $\mathrm{x}$ virginiana-like 3 .

b Mating types: A1, A2, A1/A2 (selfsterile, forming oogonia with both A1 and A2 tester strains).

c Running through Fushan Arboretum (F01).

d Running through Castanopsis-Machilus forest F02 in Fushan.

e running through Castanopsis-Machilus forest close to Fushan.

${ }^{\mathrm{f}}$ A typical Phytophthora colony was growing from plated baiting leaves but was overgrown by a fastgrowing Pythium species before subculturing.

g Phytopythium vexans also isolated.

h Downstream of Castanopsis-Machilus forest F15 in Lenhuachih.

i Running through subtropical evergreen lowland monsoon forest F16.

j Very fast current after a typhoon. 


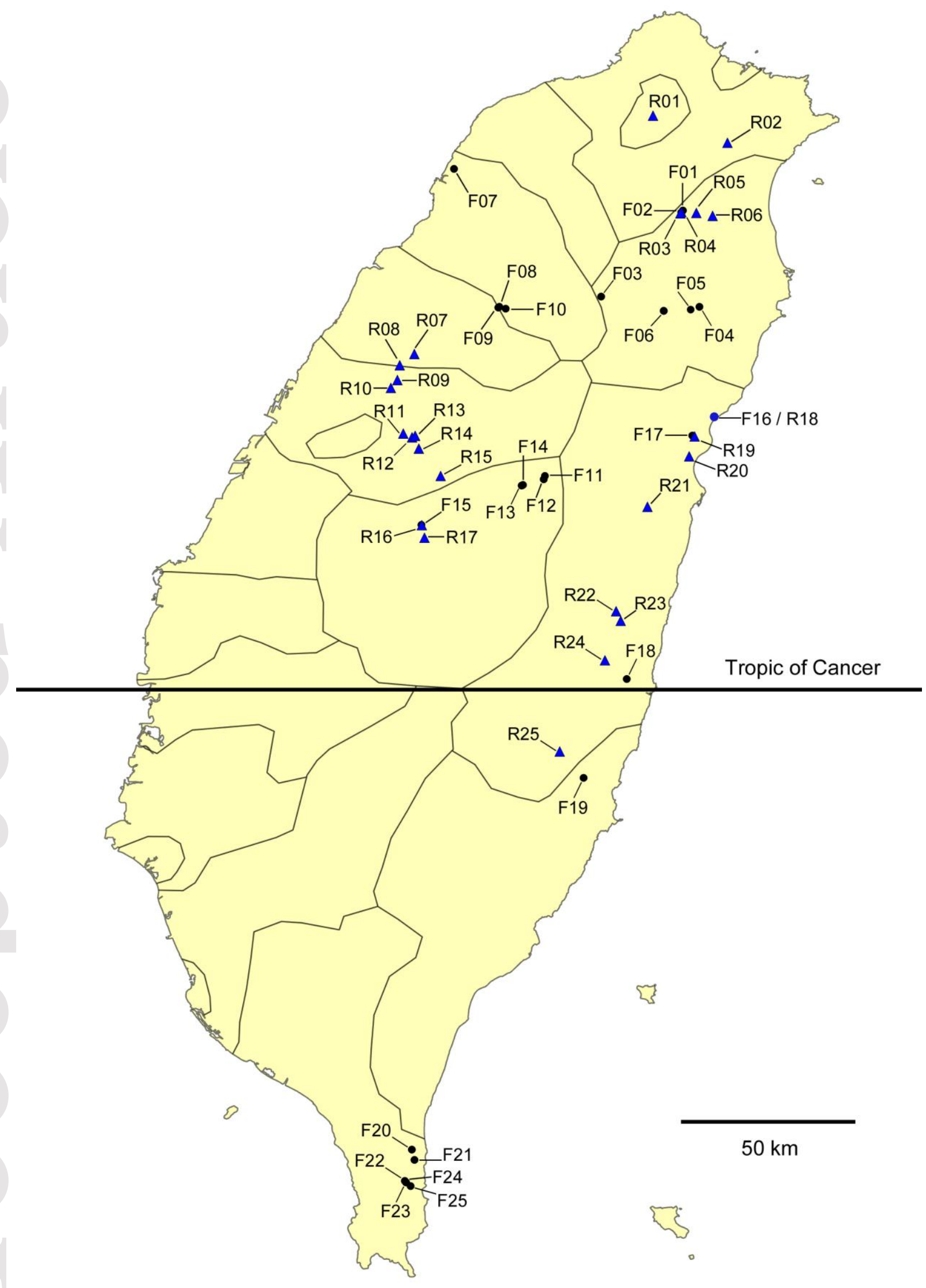

This article is protected by copyright. All rights reserved. 

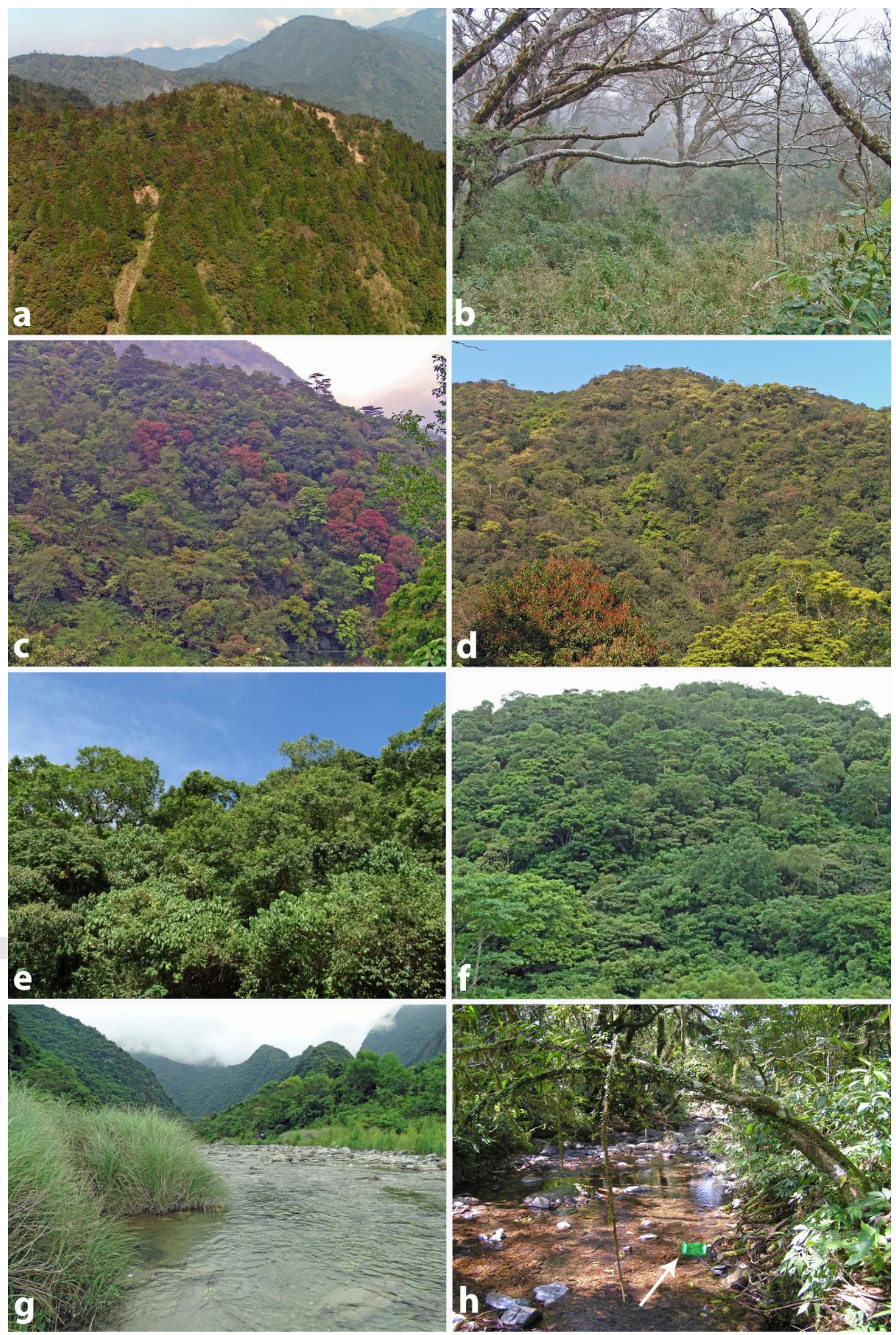

This article is protected by copyright. All rights reserved. 


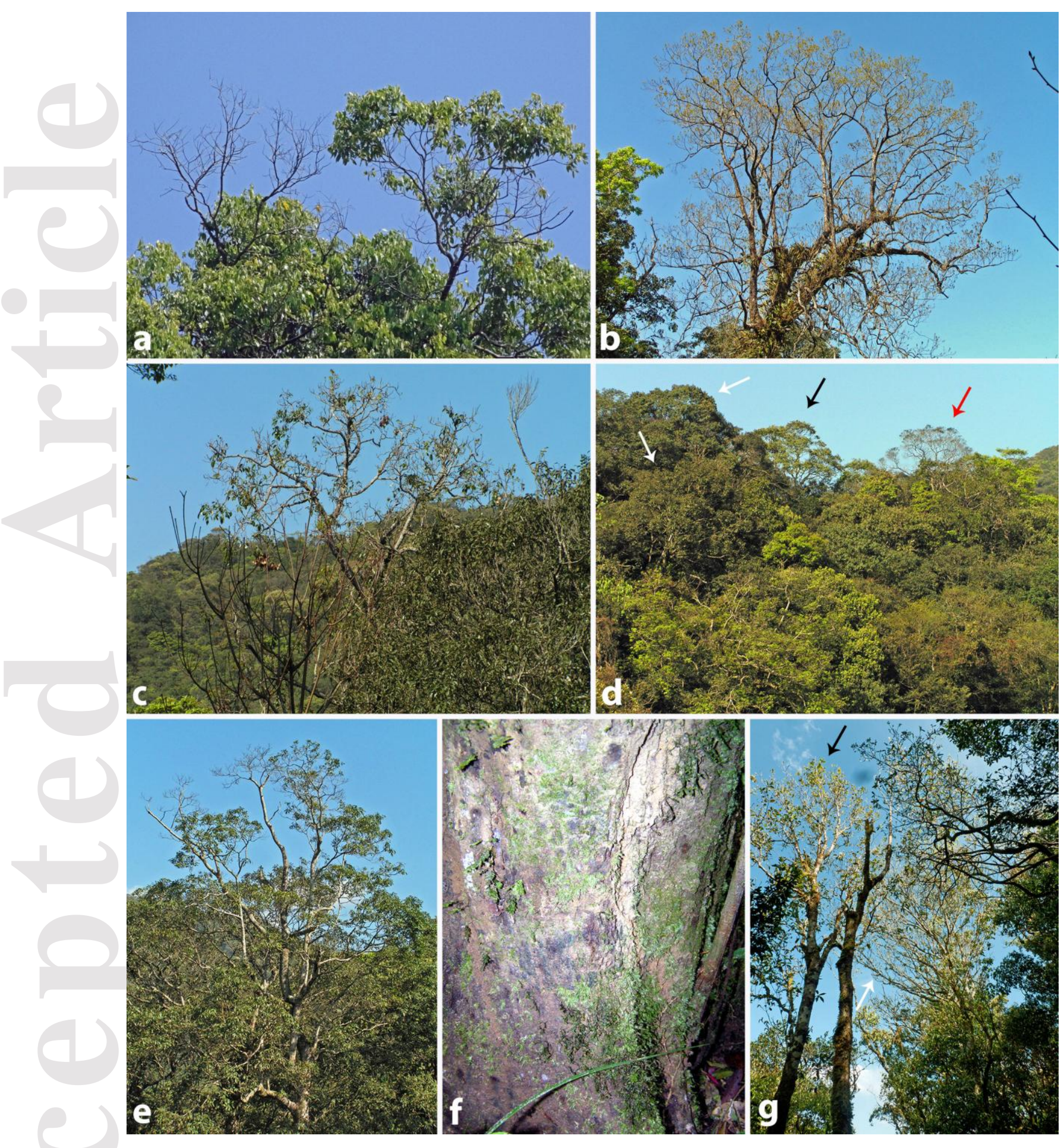

This article is protected by copyright. All rights reserved. 


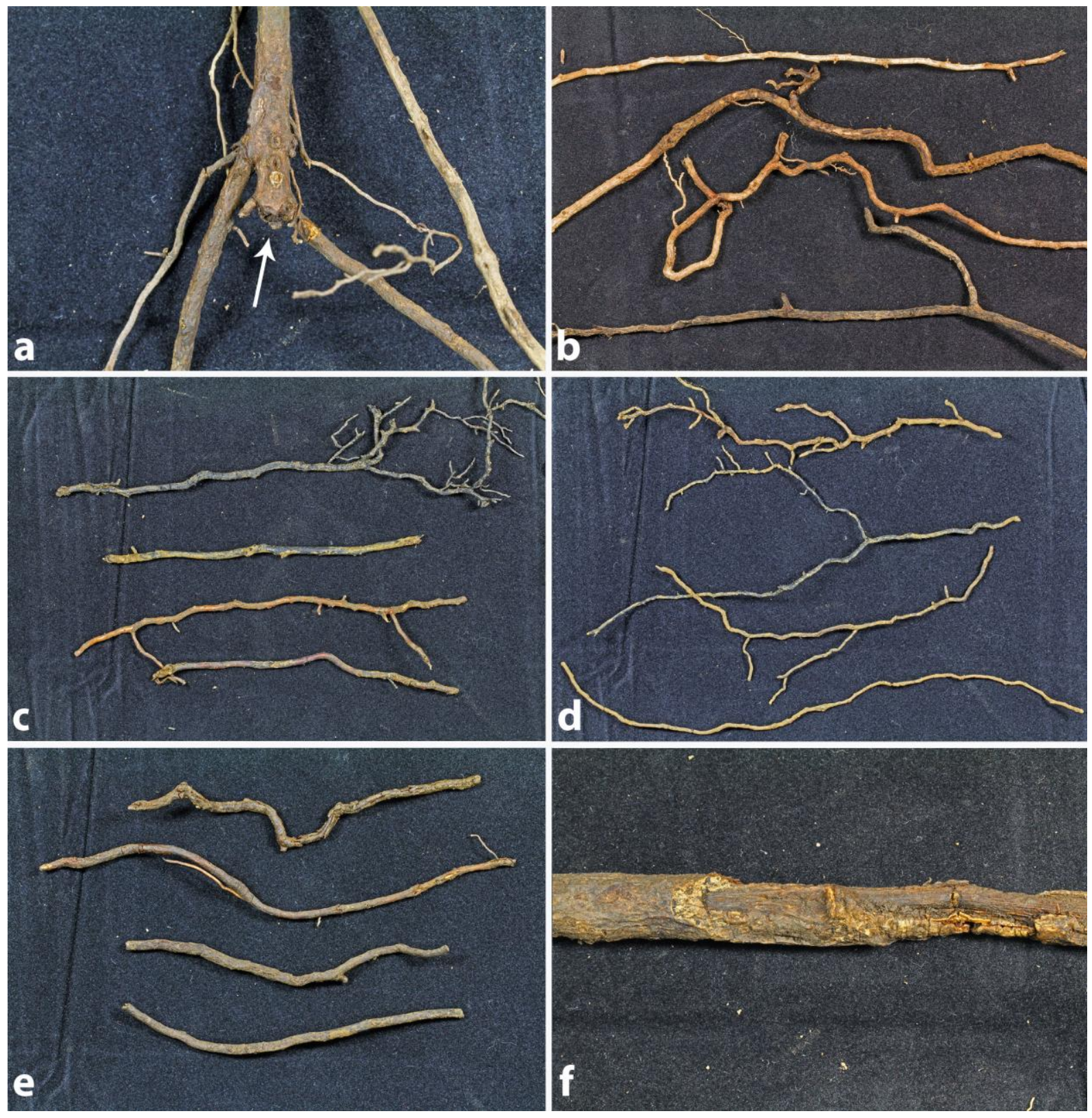

This article is protected by copyright. All rights reserved. 